\title{
WestVirginiaUniversity
}

THE RESEARCH REPOSITORY @ WVU

Graduate Theses, Dissertations, and Problem Reports

2021

\section{"A Long Life in Music:" The Career and Legacy of Ann Schein}

Anthony William Gray

West Virginia University, awg0006@mix.wvu.edu

Follow this and additional works at: https://researchrepository.wvu.edu/etd

Part of the Musicology Commons, Music Pedagogy Commons, and the Music Performance Commons

\section{Recommended Citation}

Gray, Anthony William, "'A Long Life in Music:" The Career and Legacy of Ann Schein" (2021). Graduate Theses, Dissertations, and Problem Reports. 8094.

https://researchrepository.wvu.edu/etd/8094

This Dissertation is protected by copyright and/or related rights. It has been brought to you by the The Research Repository @ WVU with permission from the rights-holder(s). You are free to use this Dissertation in any way that is permitted by the copyright and related rights legislation that applies to your use. For other uses you must obtain permission from the rights-holder(s) directly, unless additional rights are indicated by a Creative Commons license in the record and/ or on the work itself. This Dissertation has been accepted for inclusion in WVU Graduate Theses, Dissertations, and Problem Reports collection by an authorized administrator of The Research Repository @ WVU.

For more information, please contact researchrepository@mail.wvu.edu. 
"A LONG LIFE IN MUSIC:"

THE CAREER AND LEGACY OF ANN SCHEIN

By

Anthony William Gray

A Doctoral Research Project submitted

to the College of Creative Arts

at West Virginia University

in partial fulfillment of the requirements for the degree of

Doctor of Musical Arts in

Collaborative Piano

Lucy Mauro, DMA, Chair and Research Advisor

Peter Amstutz, DMA

Robert Chafin, MM

General Hambrick, MFA

School of Music

Morgantown, West Virginia

2021

Keywords: Ann Schein, Ann Schein Carlyss, American Concert Pianist, Women Concert Pianists

Copyright 2021 Anthony William Gray 


\title{
ABSTRACT \\ "A LONG LIFE IN MUSIC:" \\ THE CAREER AND LEGACY OF ANN SCHEIN
}

\begin{abstract}
Anthony William Gray
This research paper is devoted to the life, career, teaching and legacy of the celebrated pianist Ann Schein. Having led a remarkable career spanning more than six decades, Schein was taught by such towering figures as Mieczysław Munz, Arthur Rubinstein and Dame Myra Hess and has in turn influenced countless musicians through her own teaching. This research paper includes a detailed portrait of Schein through a biography, an interview with Schein, and interviews with six of her former students from the Peabody Institute of the Johns Hopkins University: Dr. Matthew Bengtson, Ms. Ya-Ting Chang, Dr. Inna Faliks, Dr. Mansoon Han Kim, Dr. Li-Shan Hung and Dr. Mark Markham. Also included are a timeline of her career, the programs of her historic 1980-1981 New York Chopin recital series, and a complete discography.
\end{abstract}




\section{ACKNOWLEDGEMENTS}

First, I want to express my deepest gratitude to Ann Schein for her support of this research paper as well as all her time and willingness to contribute to it. I am grateful for the opportunity to have communicated with her and gained her personal insights and reflections on her life, career and music. Also, my sincerest thanks to her students who were interviewed for this project: Dr. Matthew Bengtson, Ms. Ya-Ting Chang, Dr. Inna Faliks, Dr. Li-shan Hung, Dr. Mansoon Han Kim and Dr. Mark Markham. This research paper would not have been possible without the generous use of their time and resources.

I would especially like to thank my professor and advisor, Dr. Lucy Mauro, for all her guidance, patience and encouragement throughout my degree. I am the musician I am today because of her coaching, inspiration and motivation to be the best that I could possibly be.

I would also like to thank my committee members: Dr. Peter Amstutz, Professor Robert Chafin and Professor General Hambrick for their support, advice and generosity during my doctoral studies.

Finally, I wish to thank my wife, family and friends for everything they have done to support and provide for me throughout my life.

Anthony William Gray April 2021 


\section{TABLE OF CONTENTS}

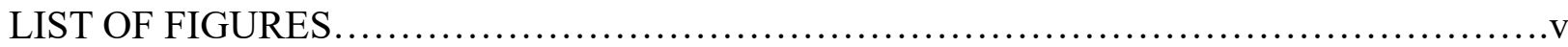

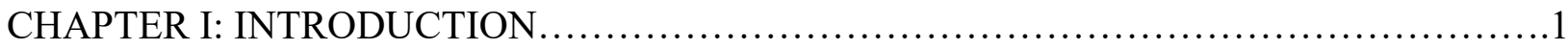

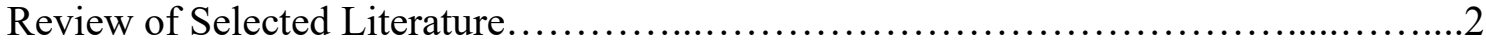

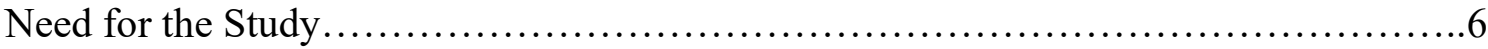

CHAPTER II: BIOGRAPHY OF ANN SCHEIN ........................................... 9

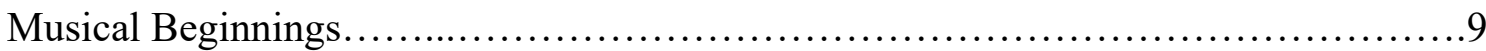

Studies with Munz and Professional Debut......................................... 14

Rubinstein, Hess and International Fame.......................................... 19

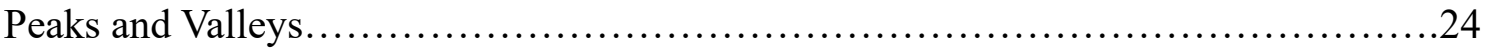

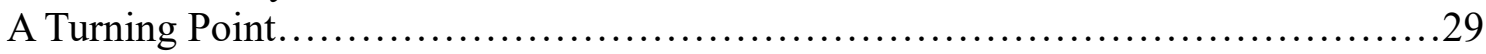

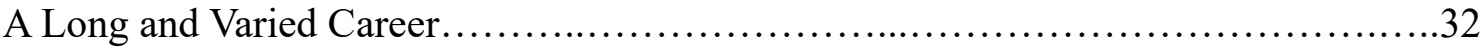

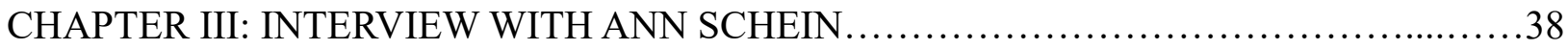

CHAPTER IV: INTERVIEWS WITH STUDENTS OF ANN SCHEIN ...........................51

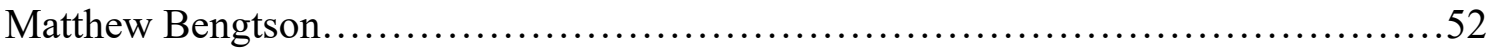

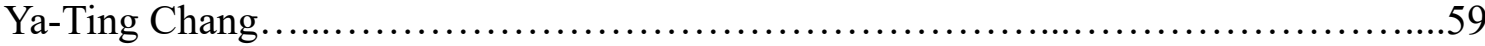

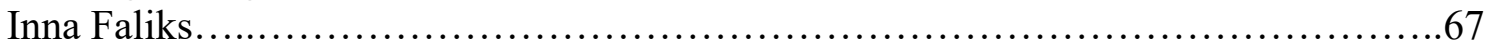

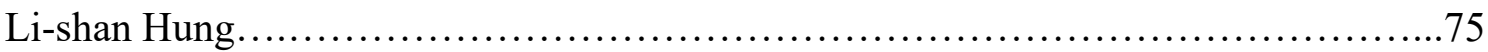

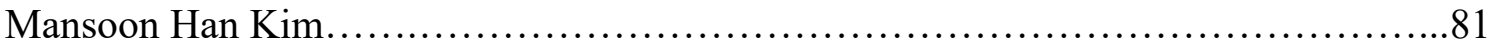

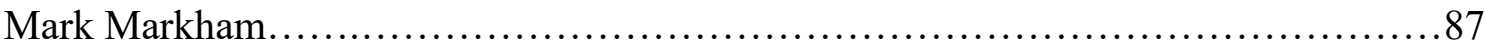

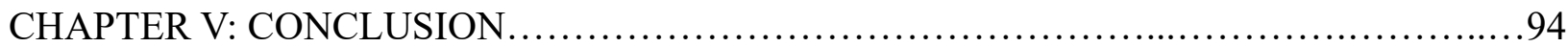

APPENDIX A: TIMELINE OF EVENTS IN THE LIFE OF ANN SCHEIN ...................99

APPENDIX B: PROGRAMS OF ANN SCHEIN'S 1980-1981 NEW YORK

CHOPIN RECITAL SERIES.................................................. 102

APPENDIX C: DISCOGRAPHY OF ANN SCHEIN..................................... 106

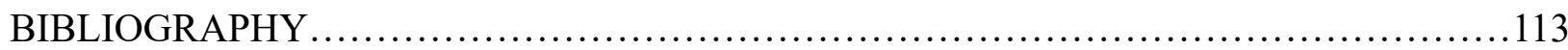




\section{LIST OF FIGURES}

Figure 2.1 Photograph of Interlochen Music Camp, 1953. Youngest ever winner of the concerto competition.........................................14

Figure 2.2 Photograph of Rachmaninoff Concerto No. 3 Recording, 1961, Vienna Musikvereinsaal with Vienna Staatsoper, Sir Eugene Goossens, conductor... .20

Figure 2.3 Photograph of White House Recital, 1963, with Ladybird Johnson.............24

Figure 2.4 Photograph of Carnegie Hall, 1975, together with Arthur Rubinstein and husband, Earl Carylss.......................................29

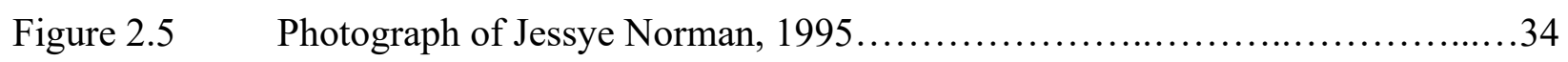

Figure 2.6 Photograph of Recital at Messiah College, Harrisburg, PA, March 2014........37

Figure $4.1 \quad$ Photograph of Matthew Bengtson......................................

Figure $4.2 \quad$ Photograph of Ya-Ting Chang.......................................... 59

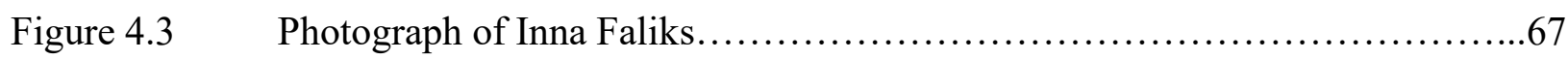

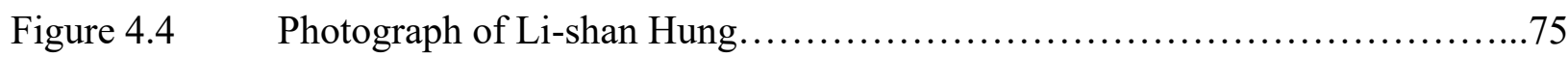

Figure $4.5 \quad$ Photograph of Mansoon Han Kim....................................... 81

Figure $4.6 \quad$ Photograph of Mark Markham.......................................... 87 


\section{CHAPTER I \\ INTRODUCTION}

This research paper is focused on the life, career, teaching and legacy of the celebrated pianist Ann Schein (b. 1939). Predicted by her teacher Mieczysław Munz (1900-1976) to have a "long life in music," Schein has led a remarkable career spanning more than six decades and accumulating such prestigious awards as a Peabody Distinguished Alumni Award by The Peabody Institute of the Johns Hopkins University and a Lifetime Achievement in the Performing Arts by the National Museum of Women in the Arts in Washington D.C. Schein was taught by such towering figures as Munz, Arthur Rubinstein (1887-1982) and Dame Myra Hess (1890-1965) and has in turn influenced countless pianists through her positions at such leading institutions as the Peabody Institute, the Eastman School of Music and the Aspen Music Festival and School among others.

This paper offers a detailed picture of Ann Schein including her studies, her career, her teachings and her enduring legacy. This is achieved primarily through a biography and interview with Schein as well as interviews with six of her former students from the Peabody Institute: Dr. Matthew Bengtson, Ms. Ya-Ting Chang, Dr. Inna Faliks, Dr. Mansoon Han Kim, Dr. Li-shan Hung and Dr. Mark Markham. Also included are a timeline of events in Schein's life, the programs of her historic 1980-1981 New York Chopin recital series and her complete discography. As a result, this research paper serves as a comprehensive resource about one of the

\footnotetext{
1 “Biography,” Ann Schein, accessed September 22, 2020, https://www.annschein.com/.
} 
most significant pianists of the twentieth and twenty-first centuries that will be of personal, historical and pedagogical value to students and musical audiences alike.

\section{Review of Selected Literature ${ }^{2}$}

As one would expect from a world-renowned performer, there is a vast body of scholarship available about Ann Schein. These available resources include biographies, interviews, articles, recordings and audio-visual content. One of the most comprehensive resources available about Schein is her own website, annschein.com. This website includes a short biography, a plethora of reviews ranging from 1950 to the present, a list of recordings, a photo gallery, a list of events dating from 2014-2020 as well as links to interviews and performance videos. Schein describes the website as "A Life in Review,"3 and it offers a wealth of valuable information about her life and career.

The most detailed biography of Schein is found in the chapter titled "Ann Schein: An American Concert Pianist in Today's World" from Cecilia Hopkins Porter's book Five Lives in Music: Women Performers, Composers, and Impresarios from the Baroque to the Present. ${ }^{4}$ Porter makes a profound statement on the significance of Schein's place in history by choosing her as the representative of the twentieth century in a book that examines one female musician

2 The resources reviewed here are only a selection of both the literature available and the literature cited in this research paper. See Bibliography for a thorough listing of available sources.

3 “Home," Ann Schein, accessed October 13, 2020, https://annschein.com/.

${ }^{4}$ Cecilia Hopkins Porter, “Ann Schein: An American Concert Pianist in Today's World," in Five Lives in Music: Women Performers, Composers, and Impresarios from the Baroque to the Present (Champaign, IL: University of Illinois Press, 2012), 148-196. 
for every century ranging from the sixteenth to the twentieth. Her biography of Schein gives insight not only into her professional career, but also her personal life including detailed looks into such areas as her family history and marriage to Earl Carlyss (b. 1939). The biography also includes a sampling of reviews written throughout Schein's career as well as a list of selected recordings.

There are several interviews with Schein available both in audio-visual and written formats. One such interview was conducted by Biola University's Center for Christianity, Culture, and the Arts (CCCA) in 2014 and is available on YouTube. ${ }^{5}$ This interview covers a wide range of topics including Schein's studies, the importance of her faith and aspects of her teaching career with several individual anecdotes. Another interview was conducted by James Litzelman and published in American Music Teacher in advance of Schein's appearance at the 2015 Music Teachers National Association (MTNA) National Conference. ${ }^{6}$ This interview also features discussions of her studies with Munz, Rubinstein and Hess as well as other topics including her connection to Rachmaninoff's (1873-1943) Piano Concerto No. 3 in D Minor, Op. 30 and her thoughts on the young pianists of today. In all of Schein's interviews, one not only learns of her vast and varied career, but is also struck by her humility, willingness to share, exquisite storytelling abilities and love for music.

5 Biola University, "Women Performers, Composers and Impresarios [CCCA Cultural Conversation]," YouTube video, 1:01:22, November 12, 2014, https://www.youtube.com/watch?v=JTdvCiNSwk0.

6 James Litzelman, “Ann Schein: Pupil, Performer, Teacher,” American Music Teacher 64, no. 3 (December 2014-January 2015): 30-34. 
Videos and articles have also been dedicated to capturing or detailing Schein's teaching. One video example of her teaching comes from a masterclass recorded at the Aspen Music Festival and School on July 17, 2014. ${ }^{7}$ In this class, Schein leads a young student, Janice Carissa, through the prelude Un reflet dans le vent (A Reflection in the Wind) by Messiaen (19081992). Schein leads the student to a greater awareness of the piece's harmony and how it resembles the writing of Debussy (1862-1918). Schein also stresses the importance of accurate rhythm and clear pedaling describing that pedaling "in all French music, but particularly Debussy, is an art." ${ }^{\prime 8}$ A written account of her teaching can be found in Jerry Wong's article "Inspiration and concrete suggestions" from the Winter 2006 edition of Keyboard Companion. ${ }^{9}$ In this article, Wong describes his experiences including lessons with Schein on the music of Chopin (1810-1849) that "were guided by deeply held principles: a commitment to the projection of beautiful tone, good balance between the hands, rhythmic coherence, clarity and a thoroughly prepared technique." 10

Schein's own perspectives of teaching and contemporary students can be found in the article "Ann Schein Teaches to Inspire Pianists" by Jeffrey Wagner in the January 2002 edition of Clavier. ${ }^{11}$ Schein emphasizes the importance of talent, patience and diligent hard work in

7 Aspen Music Festival and School, "Janice Carissa Master Class with Ann Schein," YouTube video, 24:29, December 1, 2015, https://www.youtube.com/watch?v=PYKYjis15LM\&t=6s.

${ }^{8}$ Ibid.

9 Jerry Wong, "Inspiration and concrete suggestions," Keyboard Companion 17, no. 4 (Winter 2006): 42-43.

${ }^{10}$ Ibid, 42.

11 Jeffrey Wagner, “Ann Schein Teaches to Inspire Pianists," Clavier 41, no. 1 (January 2002): $10-17$. 
achieving musical success. She also describes several of her practice techniques including a daily regimen of scales, arpeggios and difficult passages derived from repertoire as well as several rhythmic devices for developing speed, clarity and stamina.

Of course, an indispensable part of any musician's career is their performances. Throughout her career, Schein has made numerous recordings. ${ }^{12}$ For example, she has made recordings of several landmark Chopin pieces including the Four Scherzi (No. 1 in B Minor, Op. 20; No. 2 in B-flat Minor, Op. 31; No. 3 in C-sharp Minor, Op. 39; No. 4 in E Major, Op. 54); Piano Concerto No. 2 in F Minor, Op. 21; Piano Sonata No. 3 in B Minor, Op. 58 and TwentyFour Preludes, Op. 28. There are also recordings of her collaborations with artists such as soprano Jessye Norman (1945-2019), the American Chamber Players and her husband, violinist Earl Carlyss. Furthermore, Schein's performance at the 2012 Aspen Music Festival and School is available on YouTube and includes separate links of the following repertoire:

Chopin: Ballade No. 4 in F Minor, Op. 52

Nocturne in E-flat Major, Op. 55, No. 2

Liszt: Tarantella from "Venezia e Napoli,” Book II from Annees de Pelerinage

Ravel: Sonatine

Carter: Piano Sonata (1945-46), excerpt from the first movement Beyond the available audio and video recordings, there are countless reviews of Schein's performances available in articles, newspapers, her website and Porter's book.

12 See Appendix C for Schein's detailed discography. 
Schein has also largely contributed to the body of literature available about her teachers particularly Munz and Rubinstein. In the article "The music of Chopin - my legacy from Mieczysław Munz and Arthur Rubinstein" in the Winter 2006 edition of Keyboard Companion, ${ }^{13}$ she describes "the enormous influence of these two Polish giants - Munz and Rubinstein - the greatest gift of my musical life. They took me into another world." 14 Schein was also interviewed about her studies with Munz for Sora Lee's 2016 dissertation “The Life and Legacy of Mieczysław Munz" ${ }^{15}$ and subsequent documentary Munz: A Pianist's Story. ${ }^{16}$ In these sources, Schein describes her studies with Munz, shares personal anecdotes and explains many of the important things she learned from him including a wide range of repertoire and its stylistic features, the ability to derive technical exercises from repertoire, his magical fingerings as well as his "lack of emphasis on the mere technical difficulties.....and his impeccable artistic guidance." ${ }^{17}$

\section{Need for the Study}

Ann Schein is one of the greatest and most distinguished pianists of the twentieth and twenty-first centuries. As a performer, she has extensively appeared in over fifty countries and

\footnotetext{
13 Ann Schein, "The music of Chopin - my legacy from Mieczysław Munz and Arthur Rubinstein," Keyboard Companion 17, no. 4 (Winter 2006): 38-41.

${ }^{14}$ Ibid, 41. 2016).

15 Sora Lee, “The Life and Legacy of Mieczysław Munz," DMA diss., (West Virginia University,

${ }^{16}$ Munz: A Pianist's Story, DVD, produced by Lucy Mauro, 2020.

${ }^{17}$ Lee, "The Life and Legacy of Mieczysław Munz."
} 
with many of the world's leading orchestras including the Los Angeles Philharmonic, the Vienna Philharmonic, the New York Philharmonic, the Philadelphia Orchestra, the Baltimore Symphony, the Washington National Symphony Orchestra, the London Philharmonic, the London Symphony and the BBC Symphony Orchestra and conductors such as George Szell (1897-1970), James Levine (1943-2021), Seiji Ozawa (b. 1935), Sir Colin Davis (1927-2013), James DePreist (1936-2013), David Zinman (b. 1936) and Stanislaw Skrowaczewski (1923-2017). ${ }^{18}$ In addition to her performances at famed concert venues, Schein has performed at the White House and before royalty. Through her historic career, she remains a significant figure in twentieth century pianism and has gained a wealth of experiences and advice to share with aspiring musicians.

As a teacher, Schein has held several prominent positions passing on her knowledge to future generations, which she believes is her obligation. ${ }^{19}$ Through her studies with such master teachers as Munz and Rubinstein, Schein forms a crucial link with the pianists from the Golden Age of the Virtuoso. ${ }^{20}$ The knowledge gained from them is invaluable and is of significant pedagogic value to piano students today.

As mentioned above, many resources about Schein are already available. This research, however, is intended to complement, expand and compile the current scholarship. A particular focus of this paper is a gathering of more information describing Schein's teaching and the influence it has had on her students. This is addressed in Chapter IV which is dedicated to short biographies and interviews with a selection of Schein's former students. Also the interview with
18 Schein, "Biography."
19 Litzelman, 31.
${ }^{20}$ Generally regarded as pianists of the late $19^{\text {th }}$ and early $20^{\text {th }}$ centuries. 
Schein herself seeks to expand existing interviews by discussing in more detail such aspects as her technical approach to the piano, her practice routines, her advice to current students and her thoughts on the quintessential qualities for a musician.

In summation, this research paper documents Schein's life and career, highlights her significance and importance to the history of pianism and to music in general, and serves as a pedagogic record of her teachings and advice to current and future generations of students. 


\section{CHAPTER II}

\section{BIOGRAPHY OF ANN SCHEIN}

\section{Musical Beginnings}

Ann Schein was born on November 10, 1939 in White Plains, New York to George Langer Schein (1898-1942) and his second wife Kathleen Janney Lynch (?-1947). ${ }^{21}$ Schein's early life had a tragic beginning as her biological parents both died when she was very young. Her father passed away in 1942 at age forty-four, and her mother passed away five years later in 1947 while only in her thirties. After her father's death, Schein was adopted at the age of two by her father's brother, Ernest (Ernie) Isador Schein (1899-1967), and his wife, Elizabeth (Betty) Grindrod Cain (1907-1967). With her adoption, Schein became the youngest of four children in her new household. ${ }^{22}$ It was not until age fourteen that Schein was informed of her adoption as it was her adopted father's wish that it be kept secret. ${ }^{23}$ Schein accepted this new revelation with no hesitation. $^{24}$

${ }^{21}$ George's first wife, Louise Emily Mayer (1891-1927), died at age thirty-six. George and Louise had three children: George Langer Schein (Shields) (1919-1999), Louise Elizabeth Schein McDougall (b. 1921) and Bette Denver Schein MacDonald (b. 1923) (Porter, 153).

${ }^{22}$ Schein's brother Robert Louis Schein (b. 1932) became a computer programmer, and her sister Linda Schein Greenebaum (b. 1935) became a professional violinist. Unfortunately, her sister Paula Leslie Schein (1936-1947) died of nephritis at a very young age (Porter, 154).

${ }^{23}$ Porter, 151-153.

${ }^{24}$ Ann Schein, discussion with author, March 18, 2021. 
The Schein family was a very musical one. A family orchestra first came as performers to Chicago in 1893 where they participated in the World's Columbian Exposition. ${ }^{25}{ }^{26}$ Schein's grandfather, Louis Schein (1858-1931), a violinist and leader of the family orchestra, and many relatives made a living as freelance musicians in Chicago's music theaters and in the pit orchestras for silent films. ${ }^{27}$ Despite this, Schein attributes her career in music to her adoptive parents. She feels she would never have had any success in music if not for her adoptive parents due to her real parents' illness and subsequent death. ${ }^{28}$ Ernie Schein, as well as his brother George Schein, were attorneys with several prominent musical clients including the Chicago Musicians' Union and the Chicago Musical College. Betty Schein was an accomplished violinist who served as concertmaster in a local orchestra and performed occasionally as a soloist despite not seeking a career as a professional musician. It was in this musical environment that a threeyear-old Schein first played the piano by perfectly recalling "The Marine Hymn" that she heard on the radio. ${ }^{29}$ From there, Schein's musical path began.

Schein's first teachers were Mrs. Bessie Bracken (B.B.) Gunn (1881-?) and her husband Dr. Glenn Dillard Gunn (1874-1963). Dr. and Mrs. Gunn had both studied with Ferruccio Busoni (1866-1924) as well as Arthur Friedheim (1859-1932), a student of Franz Liszt (1811-1886).

25 The World's Columbian Exposition was a world's fair organized to commemorate the $400^{\text {th }}$ anniversary of Columbus' landfall in the New World. It lasted from May 1 to October 30, 1893 (Encyclopedia of Chicago).

${ }^{26}$ Ann Schein, discussion with author, March 18, 2021.

27 Porter, 152.

28 Ann Schein, discussion with author, March 18, 2021.

29 Porter, 152-154. 
Schein studied with Mrs. Gunn from 1943 to 1947 and from 1949 to $1953 .{ }^{30}$ Dr. and Mrs. Gunn "surrounded [Schein] with the aura of a great pianistic tradition, and...were friends of the finest artists performing during the $20^{\text {th }}$ century." 31 Schein recalls that "the markings [Mrs. Gunn] put into my scores were treasures, with emphasis on shapely phrasing, deep tone, use of the whole arm, subtle gradations of dynamics and artistic use of the pedal." 32 Through their acquaintances with many composers of the time, the Gunns also gave Schein an appreciation for contemporary music. Throughout her career she would perform the works of such modern composers as Elliott Carter (1908-2012), Aaron Copland (1900-1990), Ned Rorem (b. 1923) and Charles Ives (18741954), among others.

In 1945, both the Schein family as well as Dr. and Mrs. Gunn moved to Washington, D.C. Dr. Gunn had been appointed chief music critic of the Washington Times- Herald. Schein continued to grow tremendously under the tutelage of Dr. and Mrs. Gunn. She presented her first solo recital at age seven at the Young Women's Christian Association's (YWCA) Barker Hall. Three years later, she made her concerto debut at age ten performing the first movement of Beethoven's (1770-1827) Piano Concerto No. 1 in C Major, Op. 15 with the Washington Civic

${ }^{30}$ From 1947 to 1949, the Schein family moved to Manila in the Philippines while Ernie Schein worked as chief examiner of the War Damage Commission. During this time, Schein studied with the Spanish virtuoso Julio Esteban (1906-1987) (Porter, 155).

31 Litzelman, 30.

${ }^{32}$ Ibid, 31. 
Symphony Orchestra under conductor Hendrik Essers. ${ }^{33}$ Both Schein's mother and her sister Linda played in the violin section in this debut performance. ${ }^{34}$

Schein's early recitals were noted for the difficulty of her repertoire as well as her musical and pedaling abilities. Schein recalls that "when I performed Ravel's (1875-1937) "Sad Birds" ("Oiseaux tristes") and "Alborada del gracioso" from Miroirs when I was 9, one of Washington's leading pianists asked Mrs. Gunn why she had given such a young student these advanced works. 'I didn't tell her they were difficult!' she replied." ${ }^{35}$ Reviewing a solo recital performed when she was eleven years old, Dr. Gunn wrote in the Washington Times-Herald: "young Ann has a spontaneous gift of address, an intuitive grasp of style and content and, most unusual, a feeling for the modern atmospheric uses of the pedal. She played the music of the impressionists not only upon the keyboard but with liberated and blended sounds of the piano."36

Washington D.C. provided a thriving arts scene for Schein to "attend concerts each week of a quality and artistic scope of the highest caliber." ${ }^{37}$ In addition to halls and orchestras home to Washington such as the Library of Congress, the National Symphony and the National Cathedral, orchestras from Philadelphia, Boston, Chicago and Cleveland made regular visits to the city. Schein was fortunate enough to hear such world-renowned pianists as Arthur Rubinstein

33 Porter, 158.

${ }^{34}$ Kentucky Music Teachers Association, "Beethoven: My Musical Journey - Ann Schein," YouTube video, 44:59, September 25, 2020, https://www.youtube.com/watch?v=Q9K4i2uwzwc\&t=195s.

35 Litzelman, 31.

36 “Reviews,” Ann Schein, accessed September 22, 2020, https://annschein.com/reviews.

37 Kentucky Music Teachers Association. 
(1887-1982), Glenn Gould (1932-1982), Dame Myra Hess (1890-1965) and the American debut of Sviatoslav Richter (1915-1997). ${ }^{38}$ Having exposure to such a high level of performers and performances helped to shape Schein's artistic path and certainly left an immutable impression.

During the summer months of 1951 and 1953, Schein studied at the Interlochen National Music Camp in Michigan where she played both piano and cello. In the summer of 1953, Schein won Interlochen's Concerto Competition performing the first movement of MacDowell's (18601908) Piano Concerto No. 2 in D Minor, Op. 23. At thirteen years old, Schein was the youngest winner in the history of the camp. With Schein's newest success and the advancing age of Dr. and Mrs. Gunn, her parents began looking for a world-class artist teacher to continue her studies.

38 Ibid. 


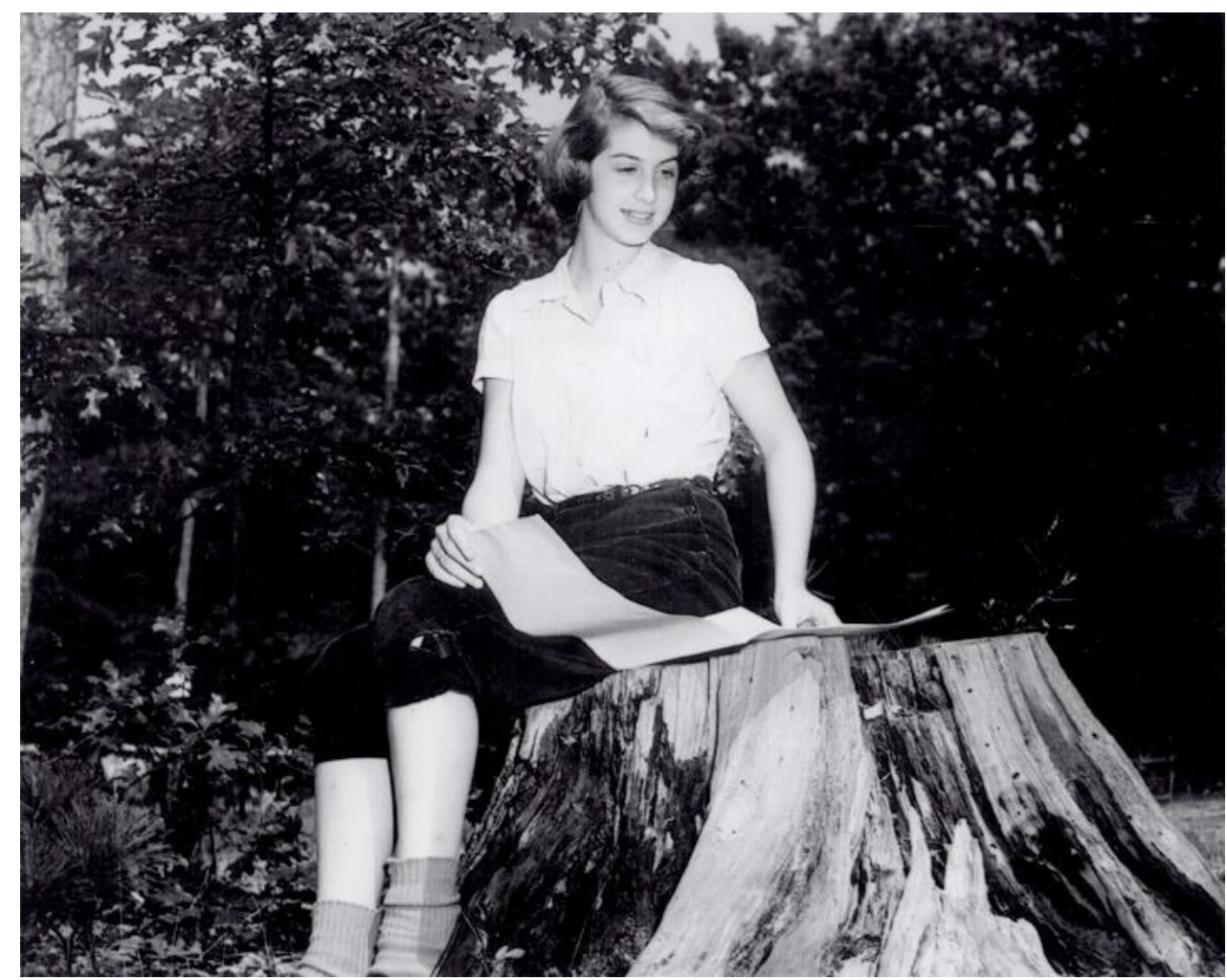

Figure 2.1 Interlochen Music Camp, 1953. Youngest ever winner of the concerto competition ${ }^{39}$

\section{Studies with Munz and Professional Debut}

In 1953, Schein's parents arranged auditions with three prominent pianists: Eduard Steuermann (1892-1964) at the Julliard School, Mieczysław Horszowski (1892-1993) at the Curtis Institute and Mieczysław Munz (1900-1976) at the Peabody Institute. The results of the three auditions could not have been more different. At the first audition, Schein overheard Steuermann tell her mother that "you should get her onto another path." 40 Following this

39 “Gallery," Ann Schein, accessed January 24, 2021, https://annschein.com/gallery.

40 Ann Schein, discussion with author, March 18, 2021. 
traumatic experience, Schein played for Horszowski who she recalls "was very gracious to my mother. He said 'she's very young, but I would like her to come back next year. I'm full now with my class, but I'm very interested and it would be wonderful if you would bring her back." ${ }^{41}$ Finally, the next day Schein played for Reginald Stewart (1900-1984), the director of the Peabody Institute, who recommended that she play for Munz. Schein remembers "falling head over heels for [Munz's] enveloping personality." ${ }^{42}$ She was accepted to begin study immediately with Munz who started an intense regimen including two-hour lessons twice weekly and “devised a 'five-year plan' of study with him (1953-1958) that he believed would solidify her technique, expand her repertoire with increasingly demanding works, and thereby launch her future as a pianist." ${ }^{43}$

Schein's parents were fully committed to Munz's plan. Her mother drove her from Washington D.C. to the Peabody Institute in Baltimore, Maryland twice a week for the next five years to her lessons with $\mathrm{Munz}^{44}$ and made certain that she followed the practice routine faithfully. In addition to her studies at Peabody, Munz asked Schein's parents to bring her to Mexico City with him during the summer months while he was on vacation. Schein's parents agreed, and Munz provided daily lessons ranging from six to eight hours during the summers of

41 Munz: A Pianist's Story.

${ }^{42}$ Ibid.

${ }^{43}$ Porter, 160.

${ }^{44}$ This was possible as Schein attended "the Holton-Arms School, a private school for girls in Washington D.C. that tailored students' academic schedules to complement their work in the arts... or whatever particular talents required special schooling" (Wagner, 14). 
1954 and 1955. Schein remarks that "it was in these summers that I truly learned how to practice with iron discipline and how to work at another level beyond anything I had experienced up to that time. ${ }^{\prime 45}$

Schein describes Munz as her "greatest mentor.... who trained her, and predicted for her, 'a long life in music." ${ }^{46}$ Munz is regarded as "one of the outstanding pianists of the last century as both an acclaimed international concert artist and teacher." ${ }^{\circ 7}$ He had studied with Busoni even becoming his assistant and demonstrator. Despite his musical legacy, Munz suffered many losses in his life including the loss of his parents and over twenty members of his family to the Holocaust, the loss of his wife Aniela "Nela" Młynarska (1908-2001) to another man (Arthur Rubinstein) and eventually the loss of his playing ability to occupational neurosis in his right hand during the mid-1940s. Despite the tragedies of his personal life, Schein recounts that to his students

"he gave his full measure of time, work ethic, miraculous fingerings for varying sizes of hands, exercises from any work being studied which could enhance a student toward greater ease technically and often to breathtaking virtuosity. He emphasized using difficult passages in all styles and compositions as exercises with the confidence that the student could feel enhanced freedom at the keyboard and thus advance more quickly to a musical understanding of each work." 48

Furthermore, Schein remarks that

"with his teaching [he] hinted at poetic and subtle effects, he left it to each individual student to express the music with their own voice in

45 Porter, 164.

46 Schein, "Biography."

${ }^{47}$ Lee, "The Life and Legacy of Mieczysław Munz."

${ }^{48}$ Ibid. 
performances. His love for Schumann (1810-1856) was one of his greatest gifts to me, as he gave me some of the biggest works, the Humoreske, Davidsbündlertänze and the F-sharp Minor Sonata in the first two years I studied with him. ${ }^{49}$

It was also Munz who gave Schein Rachmaninoff's (1873-1943) Piano Concerto No. 3 in D Minor, Op. 30 which became one of the pieces with which she is most closely associated. Munz gave her the piece in 1954 telling her "you will never play it, but it will help develop your hands and your technique."50 Schein worked diligently on the piece and gave her first performance, of over one hundred performances that she would give throughout her career, two years later in 1956 with the Peabody Symphony Orchestra under conductor Guillermo Espinosa. This initial performance was not only notable for Schein "finish[ing] the last page measures ahead of the orchestra," 51 but also for Munz breaking his chair and for marking the beginning of Schein's career-long journey with the piece. Schein recalls that

"I had heard a violent 'CRACK' in the middle of the cadenza, sounding like a rifle shot. I jumped a little bit but did not stop. Later, I was told that my teacher had been so tense during that cadenza that he split the back of his wooden seat in two! This performance began a long and unforgettable journey with this phenomenal work, taught to me with such consummate skill that I was able to perform it again and again with ever-increasing stamina and greater understanding of its tremendous emotional power" 52

49 Litzelman, 31.

${ }^{50}$ Ibid, 34.

${ }^{51}$ Lee, "The Life and Legacy of Mieczysław Munz."

${ }^{52}$ Litzelman, 34. 
Following on this success, Schein made her professional debut in Mexico City in 1957 with a tour-de-force three-week schedule that included performances of Rachmaninoff's Third Concerto, Tchaikovsky's (1840-1893) Piano Concerto No. 1 in B-flat Minor, Op. 23 and concluded with a solo recital. On the morning of her debut, a massive earthquake struck Mexico City. Schein recalls walking with her parents to the hall to see if anyone had come hours after an earthquake and finding that "the orchestra, the conductor, and 1,000 people had arrived to hear music in a time of profound shock to the city." ${ }^{33}$ Despite the trauma experienced that day, reviews of Schein's performance were glowing. El National wrote "the young pianist possesses a complete dominion of her instrument... moreover, she revealed that she is an interpreter extraordinarily intuitive and personal," while Universal said, "in spite of her seventeen years, she demonstrated astonishing musical superiority... Ann Schein impressed us above all with the lucidity of her spirit, the force and brilliance of her pulsation, the exquisiteness of her touch and the clarity of her execution. We salute in her a great artist of the future." ${ }^{54}$ Shortly following her successful debut, Schein made a European tour of twelve countries in 1958. Munz's five-year plan that commenced in 1953 had succeeded in giving Schein the training needed to launch an international performing career that would last for more than half a century.

\footnotetext{
${ }^{53}$ Wagner, 15.

54 Schein, "Reviews."
} 


\section{Rubinstein, Hess and International Fame}

With her recent debut, the early 1960s was a pivotal era in Schein's career. In 1961, she recorded both Rachmaninoff's Piano Concerto No. 3 in D Minor, Op. 30 as well as Chopin's Piano Concerto No. 2 in F Minor, Op. 21 in the same week with the Vienna State Opera Orchestra under conductor Sir Eugene Goossens (1893-1962). Shortly after the release of the recording, Halina Rodzinski (1905-1993), widow of conductor Artur Rodzinski (1892-1958) ${ }^{55}$, played Schein's recording of the Rachmaninoff concerto for Arthur Rubinstein at a dinner party at his Park Avenue apartment. Schein recounts the story that Rubinstein exclaimed "I don't want to hear another prodigy, take it off!" ${ }^{56}$ Rodzinski was persistent, however, and put the record back on. Rubinstein was so impressed that he had the guests be quiet and listen to the entire 40minute recording. He then asked who the pianist was as well as who her teacher was and consequently invited Schein, along with her parents and Munz, to come play for him. ${ }^{57}$ It was the first time the two men had met since Nela left Munz to marry Rubinstein. After their initial meeting, Schein was invited to have coachings with Rubinstein in Paris during the summer of 1961 and in both Paris and Lucerne, Switzerland during the summer of 1962.

The first piece Schein played for Rubinstein in 1961 was Schumann's Humoreske, Op. 20. Schein recalls that "Rubinstein 'seemed curiously moved and asked me to stay for lunch. He asked if I could come the next day so that I could play the Humoreske again for his wife, and for

\footnotetext{
55 Wagner, 17.

56 Biola University.

57 Ibid.
} 
their friend Fela [Krance], who was Halina Rodzinska's sister. I did, and after this experience, I was generally there twice a week for several hours, including luncheon afterward." ${ }^{n 8}$ Here, Rubinstein's love for Schumann and Munz's vision for Schein came together in a marvelous way.

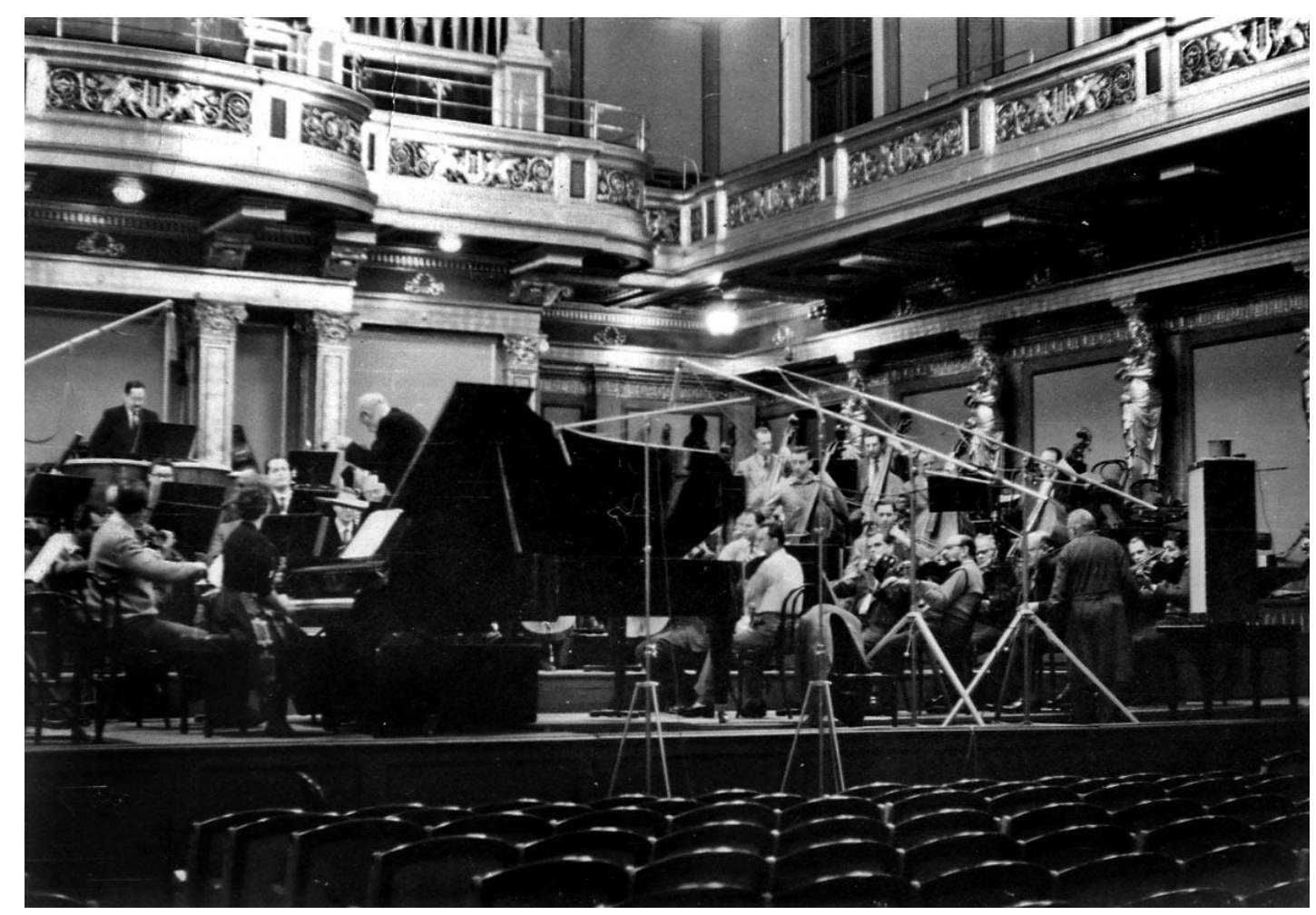

Figure 2.2 Rachmaninoff Concerto No. 3 Recording, 1961, Vienna Musikvereinsaal with Vienna Staatsoper, Sir Eugene Goossens, conductor 59

Schein's studies with Rubinstein would lead her to many new musical revelations. Upon beginning their work, Rubinstein informed Schein, "you are not here as a student, but as a

${ }^{58}$ Harvey Sachs, Rubinstein: A Life. (New York, NY: Grove Press, 1995), 335.

59 Schein, "Gallery." 
colleague. We can exchange ideas about music. I am not a teacher, and I choose not to talk about technique, fingering, etc. Also, I am against anyone imitating me. I hate that! But I want you to convince me with your own ideas. And if you do not, then we will talk about it." ${ }^{\prime 60}$ In general, Schein notes that Rubinstein "slowed many of my tempos down to a more thoughtful and beautiful pace, emphasizing vocal delivery of the melodic lines, bringing the music greater expressivity and musical depth of communication." ${ }^{\prime 61}$ One of the new revelations Rubinstein gave Schein was to see the Italian influence in Chopin's (1810-1849) Twenty-Four Preludes, Op. 28. For this, he cited the famous trip of Chopin with George Sand (1804-1876) through Italy on the way to the island of Mallorca. Schein remarks that

"I still marvel at this surprising content as I play them today, with more and more emotional attachment to each one, vividly remembering Rubinstein's exuberant descriptions and his own singing of them. He seemed to infuse each prelude with Chopin's personal vision, and made me want to run to the piano to say something more convincingly." 62

As a result of Schein's studies of Chopin, a Polish composer, with two Polish pianists, Munz and Rubinstein, she gained a greater insight into his music. She remarked, "I realized that I had learned Chopin with two Polish giants, one an introvert and subtle poet, one a world-traveled

\footnotetext{
${ }^{60}$ Ann Schein, discussion with author, March 18, 2021.

61 Litzelman, 32.

${ }^{62}$ Ibid, 33.
} 


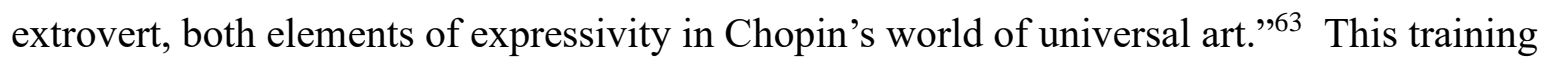
undeniably led to Schein's reputation as "one of the premier Chopin pianists of our time." 64

While she was studying with Rubinstein, Schein also received coachings from another renowned pianist, Dame Myra Hess (1890-1965). Due to a stroke that ended her playing career, Hess was quite downcast during this time. Schein describes that "it was tough and depressing to go there, but when you knew she wanted to hear you, and be helpful, you went." ${ }^{\circ 5}$ When Schein played Schumann's Piano Concerto in A Minor, Op. 54, one of Hess' most performed works, "she wanted all the tempos slower, passages more 'loved,' and there was a silent demand for far greater meaning in each note." 66

During this time, Schein received permission from both Rubinstein and Hess to study with each other simultaneously. She recounts their true reactions of each other: Rubinstein would say, “Oh yes, Dame Myra, rather boring.” While Hess would remark, “Oh, Arthur, that's fine, but he's a bit of a showoff." 67

Adding on to her studies with Rubinstein and Hess, the year 1962 brought at least two more major milestones. Schein was both added to the roster of the Russian impresario Sol Hurok

${ }^{63}$ Ibid, 32.

${ }^{64}$ Chopin, Frederic, Liner notes for A Century of Romantic Chopin, Various, Marston Records B0064CRGLY, 2011, 4 compact discs.

65 Isler's Insights, "Interview with Ann Schein and Earl Carlyss: Part 2 of 2," Facebook, September 6, 2019, https://www.facebook.com/islersinsights/posts/2141044439333002.

${ }^{66}$ Litzelman, 32.

${ }^{67}$ Ann Schein, discussion with author, March 18, 2021. 
(1888-1974) and made her Carnegie Hall debut. ${ }^{68}$ Schein's program included Beethoven's Sonata in E-flat Major, Op. 81a (“Les Adieux”), Schumann’s Davidsbündlertänze, Op. 6 and Kabalevsky's (1904-1987) Sonata No. 3 in F Major, Op. 46 as well as some shorter pieces of Chopin. The New York Journal-American was enthusiastic in its review writing that Schein was "poised on the threshold of a spectacular career... At 22, she is a phenomenal pianist.

Technically, she has remarkable keyboard mastery, tonally she can create almost any nuance she wishes, musically she comprehends much beyond her years." 69

Success continued for Schein in 1963 and 1964 as her career grew both in the U.S. and internationally. She was invited to perform at the White House in 1963 where she performed an all-Chopin program. The Washington Post wrote that she "drew the loveliest singing tone I have ever heard anyone achieve on the White House Steinway."70 In 1964, Schein was chosen by the U.S. State Department to participate in a cultural exchange. Over the next ten years, she would travel the globe performing in over fifty countries on behalf of the United States. Schein notes that she "gained a tremendous education from this experience in the international arts world."71 Seven years after her debut, Schein was already on her way to "maintain[ing] an enviable career." 72

${ }^{68}$ In 1961, Schein made a New York "pre-debut" at Lewisohn Stadium again playing Rachmaninoff's Third Concerto this time with the New York Philharmonic Orchestra and conductor Alfred Wallenstein (1898-1983) (Porter, 166).

${ }^{69}$ Schein, "Reviews."

${ }^{70}$ Isler's Insights, "Part 2 of 2."

71 Porter, 172.

72 “Ann Schein," “Johns Hopkins Peabody Institute,” December 5, 2012, accessed January 12, 2021, https://peabody.jhu.edu/alumni/award-winners/ann-schein-2/. 


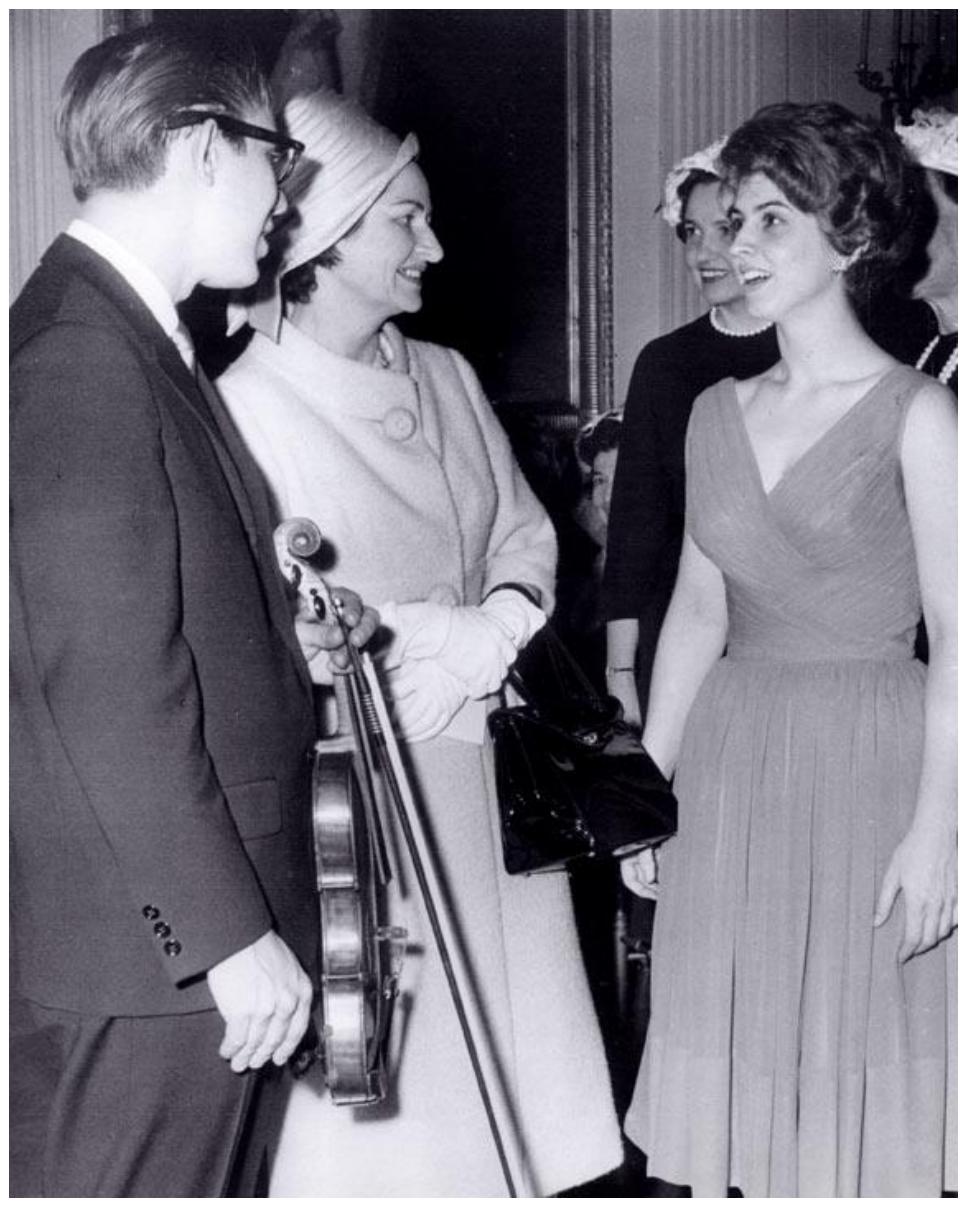

Figure 2.3 White House Recital, 1963, with Ladybird Johnson 73

\section{Peaks and Valleys}

Notwithstanding her many successes, the 1960s also brought Schein both personal and professional hardship. Schein had few concerts arranged by Hurok between 1963 and 1967. Schein recalls that Hurok lost interest in her after she accepted the invitation to perform for the

${ }^{73}$ Schein, "Gallery." 
U.S. State Department against his recommendation. ${ }^{74}$ In 1968, Schein would be dismissed by Hurok having been told "'you have the wrong personality” for an artist Hurok would sponsor."75

Despite this, Schein's career at home and abroad continued to flourish. After performing a recital in Plymouth, England in 1963, Schein's left wrist was broken in a car accident the same night. She was in good hands, however, as she was cared for by the same doctor who performed a hip operation for Sir Winston Churchill (1874-1965). The doctor's advice was to keep playing as soon as possible. After just six months, she played three concertos in the U.S. in one week: Beethoven's Concerto No. 1 in C Major, Op. 15 in Ravinia with the Chicago Symphony under Seiji Ozawa (b. 1935), Tchaikovsky’s Concerto No. 1 in B-flat Minor, Op. 23 with the Los Angeles Philharmonic under Maurice Abravanel (1903-1993) and the Schumann Concerto in A Minor, Op. 54 with the Philadelphia Orchestra at the Robin Hood Dell under Joseph Rosenstock $(1895-1985) .^{76}$

It was at such a point in her career that Schein also experienced tremendous personal loss. Schein's parents both died between June and December 1967: her father first to cancer, and her mother second to heart failure. Schein's parents had been the biggest supporters and role models of her life and career. Particularly Schein's mother had been "like a Rock of Gibraltar,"77 wise, calm and unutterably supportive. She accompanied Schein on U.S. and European tours from

\footnotetext{
74 Ann Schein, discussion with author, March 18, 2021.

75 Porter, 176.

76 Ann Schein, email to author, April 16, 2021.

77 Biola University.
} 
1957 to 1962 and was her best friend. Losing both of her parents in such a short time was devastating to Schein. These tragic losses, however, coincided with the fortuitous arrival of Schein's future husband Earl Carlyss (b. 1939).

Schein and Carlyss first met in 1966 at a performance of the Julliard String Quartet at the Library of Congress. ${ }^{78}$ Carlyss had recently joined the group as the second violinist, and Schein attended the event with her friend, pianist William Masselos (1920-1992). At a post-concert reception, Schein notes that they "took to each other "like magnets" ... and saw each other on and off for three years." ${ }^{79}$ During those years Carlyss attended Schein's 1968 performance in the famous "Last Nights" of the BBC Proms,${ }^{80}$ helped her prepare for a recording of two Prokofiev (1891-1953) Violin Sonatas with violinist Wanda Wiłkomirska (1929-2018) and talked with her father for an hour during a party at her parents' home. "To Ann, that meant that Earl was 'ok' as far as her father was concerned. And that was the only time her father, who was no longer alive when they married, met him." ${ }^{81}$ Schein and her mother had attended a concert at the Library of Congress, and her mother had been able to hear Carlyss then as a member of the Julliard String Quartet.

78 Although this was the first time they met, Schein and Carlyss' relationship had been predicted earlier. When visiting Hong Kong in 1966, Schein was received at the home of concert manager Maple Quon, who entertained all visiting artists. During her visit, Quon informed Schein that "I have found your husband-to-be, who will be the love of your life" (Porter,175) referencing Carlyss who had previously visited with the Julliard String Quartet.

79 Isler's Insights, “Interview with Ann Schein and Earl Carlyss: Part 1 of 2," Facebook, September 5, 2019, https://www.facebook.com/islersinsights/posts/2141044439333002.

${ }^{80}$ Schumann's Piano Concerto in A Minor, Op. 54 with the BBC Symphony Orchestra under Sir Colin Davis (1927-2013).

${ }^{81}$ Isler's Insights, "Part 1 of 2." 
With nowhere to go for Easter in 1969, Schein asked Carlyss if she could spend it with him and his parents "who coincidently lived in White Plains, where [she] was born." afterwards the two were married on May 24, 1969 at the First Baptist Church in White Plains with Carlyss's father officiating. Schein remarked, "I firmly believe that when we married, Earl, with his joyous outlook on life and music and his irrepressible wit, had arrived in my life at just the right moment." ${ }^{\prime 33}$ Throughout their more than fifty years of marriage, the two have given myriad performances of duo and chamber works, made recordings of Rorem's (b. 1923) Night Music and Copland's (1900-1990) Violin Sonata as well as held teaching positions together at prominent institutions.

With her marriage, Schein entered a new world and phase of her career. Carlyss's father was an evangelical minister, and his family deeply religious. Schein both embraced Carlyss's faith as well as adjusted to life as a "quartet wife" often accompanying Carlyss and the Quartet on their tours. Schein also soon became a mother giving birth to two daughters: Linnea in 1971 and Pauline in 1973. After the births of their children, she frequently stayed at home with them while Carlyss traveled and performed with the Quartet. Schein recounts that "I was totally into being my daughters' 'school mom.' I did carpools, play dates, music lessons and I loved it." ${ }^{\$ 4}$ Schein was also still a traveling performer, however, and recalls being miserable when she missed her first Mother's Day due to performing in Argentina. ${ }^{85}$

82 Porter, 176.
${ }^{83}$ Ibid, 177.
${ }^{84}$ Ibid, 182.
85 Ann Schein, discussion with author, March 18, 2021. 
The year 1976 was another significant one for diverse reasons. First, Schein made her return to Carnegie Hall in March. This was her first Carnegie Hall appearance since a 1963 recital shortly after her debut. "Schein says 'the recital got only a fair reception. The New York Times critic Donal Henahan (1921-2012), Schein recalls, 'was not ebullient. He said that I was okay, but not great." 86 Later that year, Schein's beloved mentor Munz died at age 75. Munz had resented Schein's marriage not liking to picture her hands reduced to changing diapers. ${ }^{87}$ Schein along with Carlyss and her two daughters visited him daily in a clinic in White Plains after he suffered a heart attack in 1975, and he was often able to visit them in their Scarsdale home. Despite both the gains and losses of the previous years, the 1980s were about to witness several new developments and successes in Schein's career.

${ }^{86}$ Porter, 183.

87 Ann Schein, discussion with author, March 18, 2021. 


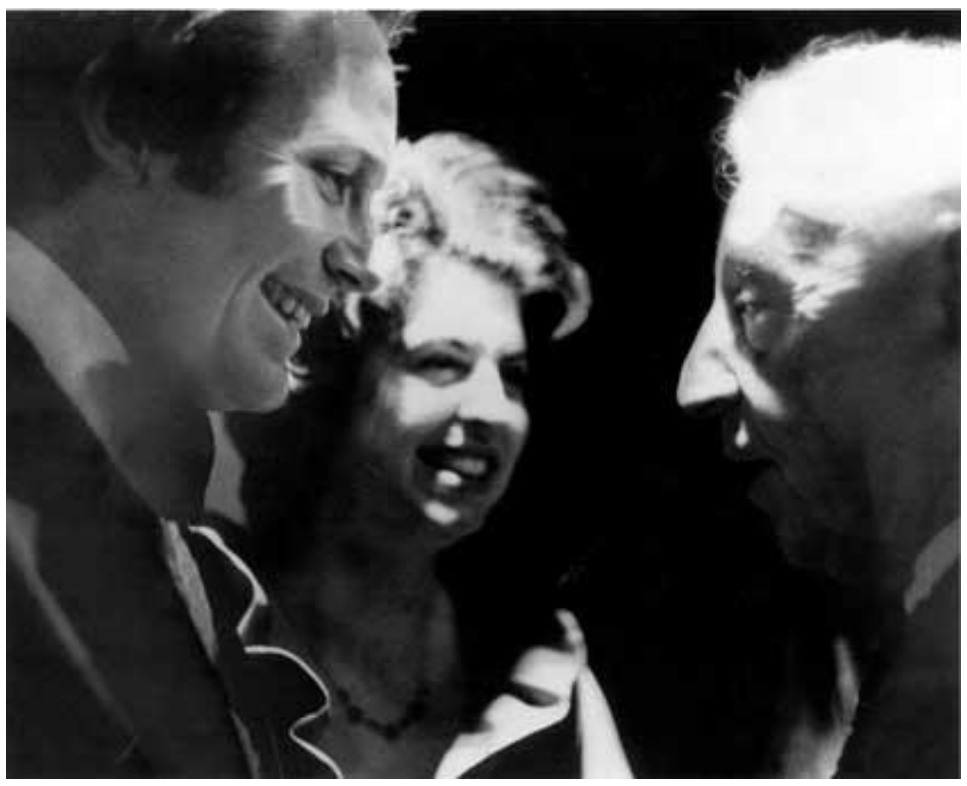

Figure 2.4 Carnegie Hall, 1975, together with Arthur Rubinstein and husband, Earl Carylss ${ }^{88}$

\section{A Turning Point}

In 1978, the publicist Alex Williamson suggested that Schein perform a cycle of allChopin concerts at Alice Tully Hall in New York. ${ }^{89}$ Schein was reluctant to accept the project both due to feeling "indecisive about her professional future" 90 as well as the need to "find her own way with the music" after learning it "under two enormous influences - Munz and

\footnotetext{
88 Schein, "Gallery."
}

${ }^{89}$ One of Williamson's goals with the series was to get Schein a new manager. Schein was placed on a three- year contract with Harold Shaw (1923-2014) but received no engagements from him (Ann Schein).

${ }^{90}$ Porter, 183. 
Rubinstein." ${ }^{91}$ Williamson persisted, however, and Schein agreed to the project two years later.

Schein was wary of Rubinstein's reaction but, fortunately recalls that

"Rubinstein heartily approved of my decision to undertake the series and gave me many lessons as I prepared for the project in 1980. He talked about pacing in the ballades and sonatas. My tendency was to drag things out, and he helped me to tighten the structure and play more directly and simply." 92

Schein also recounts Rubinstein's most poignant request when he asked, "could you play me some of the songs? I have not heard them since my youth." He wept when he heard them again. ${ }^{93}$

Between October 1980 and March 1981 Schein presented a series of six concerts. It was "the first Chopin cycle presented in New York in 35 years." ${ }^{94}$ Schein performed the complete sonatas, ballades, scherzos, impromptus, preludes, and études as well as a selection of smaller pieces, concertos, chamber works and songs. ${ }^{95}$ Schein's collaborators for the series were soprano Kristine Ciesinski (1952-2018), cellist Joel Krosnick (b. 1941), pianist Charles Wadsworth (b. 1929), her husband violinist Early Carlyss as well as the Jupiter Symphony conducted by Jens Nygaard (1931-2001). All six concerts were sold-out and the reviews ecstatic. Newhouse News Service wrote:

"Lincoln Center's Alice Tully Hall has been the setting for one of this season's musical highlights... Miss Schein must be recognized as one of today's outstanding keyboard artists, certainly one of the most wonderfully satisfying

\footnotetext{
91 Wagner, 16.

92 Ibid, 16.

93 Ann Schein, email to author, April 16, 2021.

94 Schein, "Biography."

95 See Appendix B for a detailed program listing of each recital.
} 
interpreters Chopin has ever had...Enthusiasm shines in her stage presence and in her music. Everything she plays emerges gracefully and with complete spontaneity, growing out of the poise with which she lives, the assurance of an astonishing technique and her full understanding of style and mood." 96

Despite her initial reluctance, Schein notes that "agreeing to the series was probably a turning point in my artistic life and certainly the greatest event in my career up to that point." ${ }^{\prime 97}$

The year 1980 was an eventful one for Schein that witnessed another new artistic venture. Despite having never taught, Walter Hautzig (1921-2017), also a former student of Munz, asked Schein to come to Peabody Institute where he was teaching to meet the director and the dean. There was a part-time position open, and Hautzig wanted her to teach where he was teaching and where Munz had taught her. Both the director, Elliott Galkin (1921-1990) - conductor of her first performance of Tchaikovsky's Piano Concerto in B-flat Minor, Op. 23 - and the dean, Irving Lowens (1916-1983) -former music critic of Washington's Evening Star who reviewed many of Schein's early performances - wanted her for the position. Schein needed two letters of recommendation for the job which she gratefully received from Menahem Pressler (b. 1923) and Beveridge Webster (1908-1999).$^{98}$ Specifically Pressler impressed to her that in beginning to teach she "would learn to articulate in words hitherto only deeply felt musical ideas." 99

\footnotetext{
96 Schein, "Reviews."

97 Wagner, 16.

98 Biola University.

99 Litzelman, 33.
} 
Schein did not know what to expect from teaching, but states that it was like a magical happening. ${ }^{100}$ She had only three students during her first year of teaching. This number steadily increased year by year, however, until she had a full-time position and up to nineteen students. In 1986, Carlyss retired from the Julliard Quartet and also joined the faculty at Peabody as Coordinator of the String Department and Chamber Music.

Schein describes beginning to teach as "one of the most profound moments in my musical journey...It took only one student for me to realize that this was the crowning gift - the opportunity to give back and to pass on to the next generation of aspiring talents all the gifts and experiences I had had"101 and to delve more deeply into the music. Schein and Carlyss both taught countless numbers of students at Peabody until their retirement in 2001. With her highly successful Chopin concerts and her teaching appointment at Peabody, Schein's career had truly reached a turning point.

\section{A Long and Varied Career}

The next years of her career saw Schein embark on new musical collaborations, accept additional teaching positions, receive distinguished honors and give milestone performances. From 1982-1987, Schein performed with the American Chamber Players, "an ensemble in the Washington-Baltimore area made up of seasoned musicians of the highest caliber." ${ }^{102}$ During

100 Ann Schein, discussion with author, March 18, 2021.

101 Kentucky Music Teachers Association.

102 Porter, 188. 
Schein's tenure, the group held a residency at the Library of Congress, performed throughout the United States as well as internationally including at such venues as the Opéra national de Paris and made several recordings of contemporary compositions. Schein describes that her time with the group made her feel more at home in the chamber music repertoire. The group performed over fifty contemporary pieces as well as standard repertoire. ${ }^{103}$

From 1992 to 1995, Schein performed frequently with American soprano Jessye Norman (1945-2019). The two had been friends since performing together in 1965 at a Sigma Alpha Iota convention in Minneapolis and Norman had even sung at Schein's wedding in 1969 performing Schumann's Frauenliebe und -leben, Op. 42, minus the final song. Their performances included several tours in Brazil where the Jornal do Brazil wrote "the charisma of the exceptional American soprano transformed the most traditional of song recital forms and songs into a grand artistic statement...she had the outstanding accompaniment of pianist Ann Schein who was perfect in all composers and styles." 104 In 1995, Schein appeared with Norman on her recording of Lieder by Alban Berg (1885-1935).

103 Ann Schein, discussion with author, March 18, 2021.

104 Schein, "Reviews." 


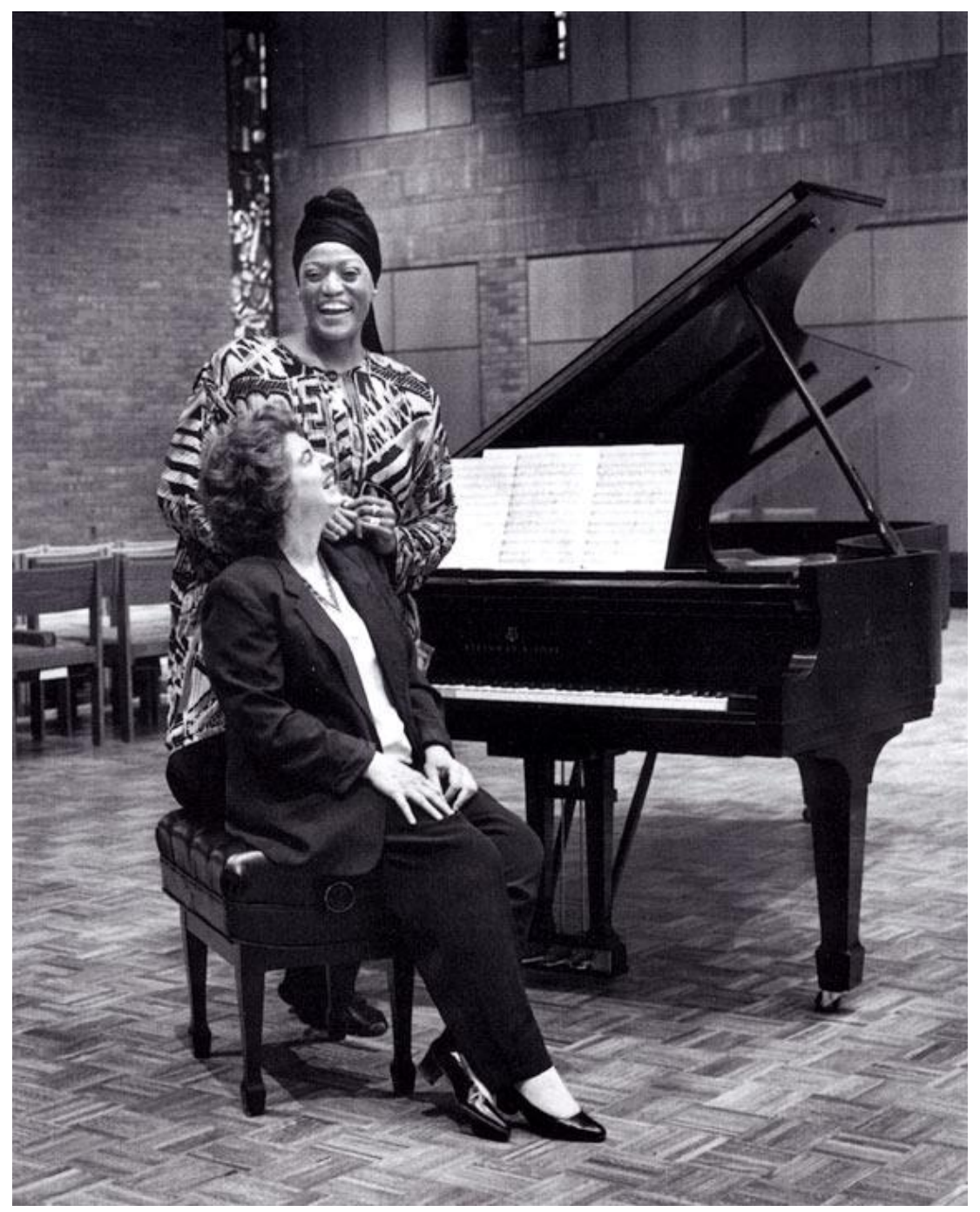

Figure 2.5 Jessye Norman, $1995^{105}$

In 1984, Schein was invited to join the faculty of the Aspen Music Festival and School as an Artist Teacher. Schein had been regularly attending Aspen with her husband as the Julliard Quartet performed and taught there since 1969. During the 2006-2008 seasons, she received the Victoria and Ronald Simms Chair "in special recognition of her teaching prominence."106 Schein

105 Schein, "Gallery."

106 “Ann Schein,” Aspen Music Festival and School,” accessed January 12, 2021, https://www.aspenmusicfestival.com/students-welcome/admissions/artist-faculty/ann-schein-1/. 
was a member of the Aspen faculty until 2016. At Aspen, Schein gave over 90 performances of solo, chamber works, and concertos as well as taught hundreds of students from around the world.

In addition to Peabody and Aspen, Schein has held other prominent teaching positions. She was a Visiting Faculty member at Indiana University from 2008-2009, a Visiting Professor at the Eastman School of Music from 2015-2016 and currently a part-time faculty member at the Mannes School of Music since 2016. Schein also taught briefly at Stony Brook University. Beyond her faculty positions, Schein has also given masterclasses and residencies at numerous locations nationally and internationally. Furthermore, she has served on the jury of several competitions including the International Piano Competition in Panama, the Astral National Auditions, the Naumburg Competition, the San Antonio International Piano Competition, the Gina Bachauer International Piano Competition, the Mieczysław Munz Competition, the Nadia Reisenberg Piano Competition at the Mannes School and other competitions at The Julliard School as well as the Manhattan School of Music. Schein remains active, passing on the legacy of her teachers to the next generation.

Schein recently received several prestigious honors in recognition of her legendary career. In 2012, she received the Peabody Distinguished Alumni Award for her "distinguished professional achievement as an internationally acclaimed performing and recording artist, and as a beloved teacher."107 In 2015, she gave a recital and video presentation at the Music Teachers

107 Johns Hopkins Peabody Institute. 
National Association (MTNA) National Conference in Las Vegas ${ }^{108}$ where she "was presented with an inscribed Tiffany gold clock and honored for her more than 50 years as a Steinway artist." 109 In 2018, she received a Lifetime Achievement in the Performing Arts by the National Museum of Women in the Arts in Washington D. C.

Also in recent years, Schein has kept an active performing schedule and given concerts observing important milestones. In 2019-2020, she performed two concerts celebrating the $40^{\text {th }}$ anniversary of her 1980-1981 New York Chopin recital series. She first performed Chopin’s Piano Concerto No. 2 in F Minor, Op. 21 with the Peabody Symphony Orchestra under conductor Edward Polochick. Secondly, Schein gave an all-Chopin recital ${ }^{110}$ at Carnegie Hall in March 2020 as part of the Key Pianist Series. ${ }^{111} 112$ Roman Markowicz of ConcertoNet.com wrote of her interpretation of the Polonaise-Fantaisie, Op. 61:

108 The author was very fortunate to have attended this event where he first became familiar with Schein. Her recital consisting of Beethoven's Sonata No. 26 in E-flat Major, Op. 81a, ("Les Adieux"); Schumann's Davidsbündlertänze, Op.6 and Chopin's Sonata No. 3 in B Minor, Op. 58 was a particularly inspiring event.

109 Schein, "Biography."

110 Schein's program for this recital included the following works: Polonaise-Fantaisie in A-flat Major, Op. 61; Nocturne in E-flat Major, Op. 55, No. 2; Sonata No. 2 in B-flat Minor, Op. 35 and Twenty-Four Preludes, Op. 28.

111 This was Schein's second performance on the Key Pianists Series following her first in 2016.

112 Schein's performance took place on March 11, 2020 which was the last day Carnegie Hall was open before closing due to the COVID-19 pandemic. 
"it should thus come as no surprise that her rendition of that magisterial work was one of the most convincing, credible, and persuasive that this listener has heard in a long time. Ms. Schein was unfussy in her delivery and it was all done in a most natural manner: listening to her, one had a rare impression that this simple, unassuming pianist conveys just what the composer had in mind." 113

Schein's career of teaching and performing continues to grow as she fulfills the prediction of her great mentor Miezyslaw Munz of "a long life in music.",

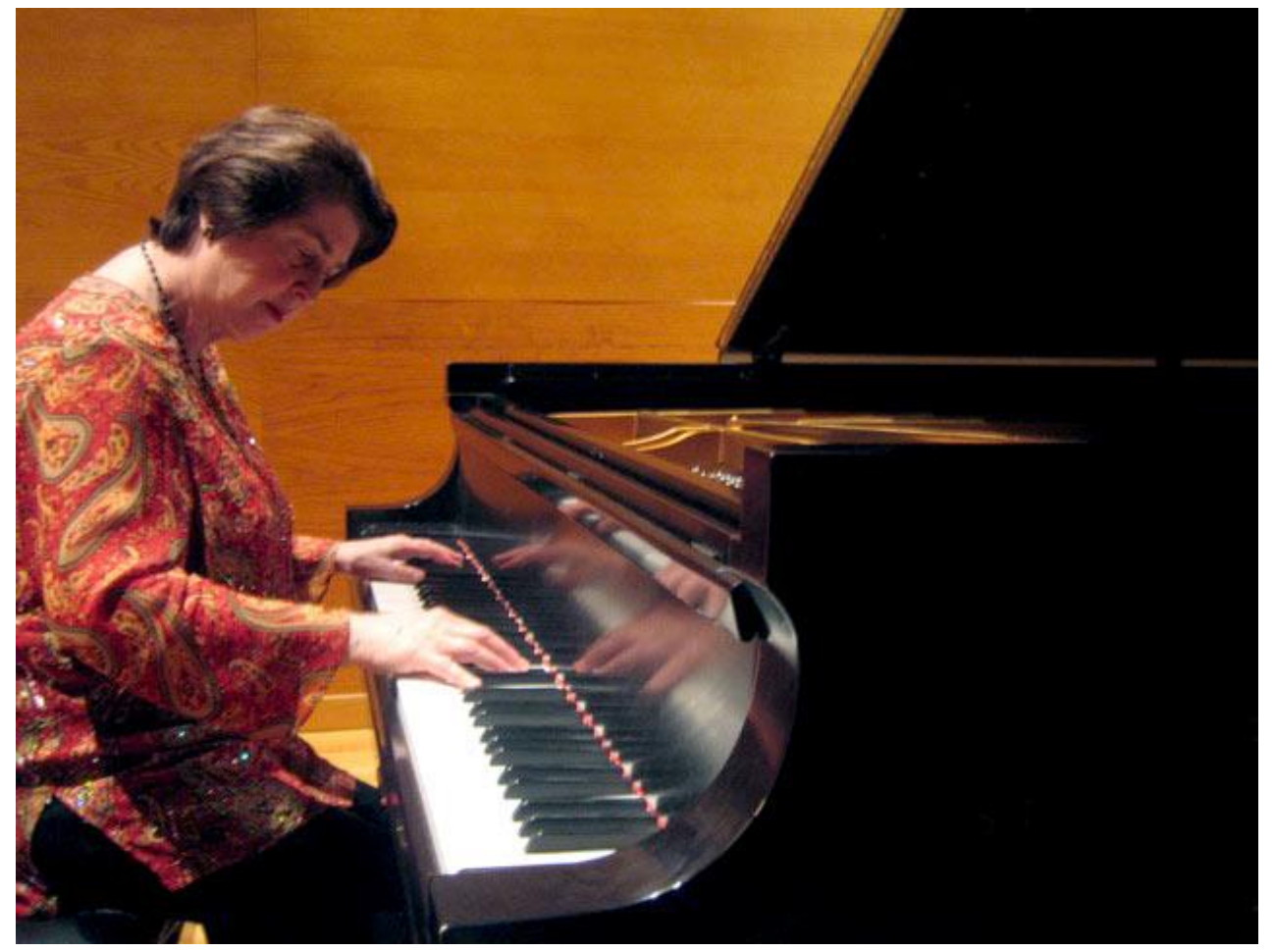

Figure 2.6 Recital at Messiah College, Harrisburg, PA, March $2014^{115}$

113 Roman Markowicz, "Chopin's interpretations that composer himself might have approved of," ConcertoNet.com, accessed January 12, 2021, http://www.concertonet.com/scripts/review.php?ID_review=14489.

114 Schein, "Biography."

115 Schein, "Gallery." 


\section{CHAPTER III \\ INTERVIEW WITH ANN SCHEIN}

The following interview was conducted by email with the author and contains Ann Schein's reflections on such topics as her early training and career, her personal connections to repertoire, her practice routines, her advice to musicians and her faith. Topics that are widely discussed in other resources, particularly her studies with Munz and Rubinstein, are not addressed directly. The purpose of this interview is to provide personal insight into Schein's life and career and offer pedagogic as well as practical advice to students.

\section{Before your studies with Munz, what was your early piano training like?}

My earliest piano teacher was Mrs. Glenn Dillard Gunn, wife of pianist, critic and founder of a Music School in Chicago, Glenn Dillard Gunn. Both were American-born pianists and had taken advanced studies in Berlin with Busoni and also with Arthur Friedheim, protégé and secretary to Franz Liszt. The Gunns accepted me as a student from the age of four, and when they moved to Washington, DC in 1945, our family also moved from Chicago to Washington. Dr. Gunn had been appointed the leading music critic for the Washington Times-Herald, and Mrs. Gunn established a piano studio in the city. I studied with her from the age of four to thirteen when I went to Peabody Conservatory. I was accepted as a Special Student of Mieczysław Munz in 1953.

My training with the Gunns was unusually nurturing. They knew all of the greatest artists in the early years of the 20th century, and I was surrounded at every lesson by their conversations 
and intimate knowledge of the performing arts and their personal acquaintance with the artists themselves. During the summers of 1951-53, I attended the National Music Camp at Interlochen, Michigan. As the Gunns had known Edward MacDowell personally and being champions of American composers, Mrs. Gunn had given me his D minor concerto. Entering the annual concerto competition during my second summer with this concerto, I was awarded the First Prize and became the youngest winner in the camp's history.

It was at that moment that my parents made the decision to arrange for me to audition with three great artist-teachers for advanced piano study. With the Gunns' approval, they chose Eduard Steuermann at Juilliard, Mieczysław Horzowski at Curtis, and Mieczysław Munz at Peabody. When Munz accepted me as a Special Student in his Peabody class, we never looked back, commuting from Washington to Baltimore several times a week for the next five years.

\section{How would you describe your technical approach to the piano?}

I would not say that I had ever been given a "technical approach" by any of my teachers. Mrs. Gunn guided me from my earliest age when I did not have long enough legs to reach the pedals! She gave me only the best music by the finest composers. I was given works of Scarlatti, Bach, Haydn, Mozart, Beethoven, Schumann, Debussy, Ravel, and works of some of the early American composers. She emphasized a calm, natural position of the hands, expressive dynamics, and a very sensitive approach to artistic pedaling. When I gave my yearly recital in her studio at age 11, the program included two pieces from Ravel's Miroirs, "Oiseaux tristes" and “Alborada del gracioso.” Dr. Gunn wrote a review of this recital especially mentioning my use of advanced pedal effects. Busoni was famous for his innovative use of the pedal, so perhaps they 
had been inspired by his artistry and imagination when they studied with him in Berlin. When I went to Munz, we learned that he had also studied in Berlin with Busoni, and at 19 had already become his assistant. He told my parents when he accepted me and that there would be nothing to change, and that my training with Mrs. Gunn had been excellent. He asked my parents if they would agree to three to five years of his more concentrated training, musically and technically, in order to develop greater strength, virtuosity and musicianship to carry me into what he predicted would be "a long life in music." My parents unhesitatingly agreed, and my life and goals became completely dedicated toward a future in music.

\section{One of your early reviews spoke of your special skill with pedaling, which can be a challenging area for pianists. Do you have any thoughts you would like to share about pedaling?}

I find that in teaching during the past years, emphasis on good, clear, musical pedaling has deteriorated. I cannot tell the reason for this, but it is a constant subject in almost every lesson that I give. In some of my recent Master Classes, I even warn the poor student that I will lie on the floor under the piano and work their feet correctly on the pedal for them! For instance, in particularly the works of Chopin, there is a special hand and foot coordination that requires that on each note of a melodic line, the fingers need to make the tone on the key first, and the foot must catch that tone AFTER the finger is depressed - a very quick motion of the foot to catch and send its sound vibrating into the air! It is an effect that brings enhanced beauty to the sound - perhaps imitating the voice, which was something innate to Chopin's soul and spirit! Definitely, it requires very acute ear response to harmonic changes and shifts, and if this is 
established early enough, becomes instinctive. Today, many students rely too much on what they see printed in their scores — often accurate, but often too vague. Many times the result is pedaling arbitrarily held through conflicting harmonies. Munz and my early teachers understood this profoundly and gave invaluable direction.

\section{Throughout your career you have traveled to over fifty countries performing and teaching countless numbers of students. What do you consider to be the most significant achievements or accomplishments of your career?}

1. My debut in Mexico City in 1957: a major earthquake happened, shaking the city in the very early hours of the Sunday morning of my debut concert at 11:00AM, knocking out all electricity and shutting down communication. I walked to the hall with my parents. We found everything there, the orchestra, conductor, and over a thousand people in the audience, waiting for the inspiration of music despite the crisis. It was my earliest experience of the healing power of music, and my first important test at the age of seventeen performing under circumstances entirely out of anyone's control.

2. In 1958, I was invited by Richard Kapp to make a debut recording for his label, Kapp Records. It was an album of Études by a variety of composers including many of Chopin. I made two more solo albums for Kapp between the years of 1958 and 1960. In 1961, I made recordings of two concertos, the Rachmaninoff 3rd Concerto and the Chopin $\mathrm{f}$ minor Concerto. These recordings took place in Vienna, with the Vienna Staatsopera Orchestra under English conductor, Sir Eugene Goossens, in the city's most famous concert hall, the Musikvereinsaal. The reviews 
for these recordings were unusually enthusiastic and helped to propel my career into a higher level. ${ }^{116}$

3. My recital debut in Carnegie Hall in 1962 under the management of Sol Hurok. Perhaps the most exciting part of this occasion was the presence of my family, Munz, and Arthur Rubinstein. It was Rubinstein who had heard my recording of the 3rd Rachmaninoff and arranged with Sol Hurok for me to join his roster of artists.

4. In 1961 and 1962 I experienced two incredible summers of advanced coaching from Arthur Rubinstein in Paris and Lucerne. Some of these lessons are described in Harvey Sachs' book on Rubinstein. ${ }^{117}$

5. Sent by Sol Hurok on two trips to the Soviet Union in 1961 and 1966 with performances throughout the country.

6. In 1963 I received an invitation to travel for the State Department as an Artistic Ambassador, with performances over the next ten years in 50 countries around the world.

7. In 1969, my marriage to Earl Carlyss, violinist and member of the Juilliard String Quartet, resulting in many joyous years performing together, plus celebrating the arrival of two beautiful daughters, Linnea and Pauline.

8. The invitation to present a year-long Chopin Series in Alice Tully Hall in 1980-81. It was the first Chopin Series to be presented in New York since the 1940's.

9. In 1980, I was invited to join the piano faculty of the Peabody Conservatory, continuing for the next 21 years.

116 See Appendix C for full citations and program listings for Schein's recordings.

117 Sachs, 334-337 and 376. 
10. In 1984, I became an Artist-Faculty member of the Aspen Music Festival and School, which included multiple solo, chamber, and Concerto performances as well as the teaching of hundreds of students during the next 35 summers.

11. Collaboration with my life-long friend and one of the world's greatest singers, Jessye Norman, during the 1990s. These years included a recording of Alban Berg songs, a trip to Brazil, plus many performances in the US.

12. I have been a Visiting Professor at Indiana University, as well as a Visiting Professor at the Eastman School, and since 2016, I have been a piano faculty member at the Mannes School of Music.

\section{What advice do you have for young and/or college-age pianists?}

While I very much believe in the individuality of each student, and while my advice to each one may be different, I can offer some thoughts applicable to aspiring pianists of any age.

a. Establishing a daily practice routine. For younger students, I recommend 2-4 hours a day with breaks after each hour depending on school or family demands. For high school and college age, I would emphasize 4-6 hours a day, without trying out a performance speed and strength too early. At this age, impatience and ambition tend to take over! Discipline should ideally have been established earlier by wise teachers!

b. In this era of computers, technological information and the quick access to abbreviated information, I would hope that students of all ages would be encouraged to read extensively about the composers, their history and the world history surrounding their lives, and a general 
appreciation of the arts. The constant widening of each student's general education will expand their imagination and expression in their performances and in their growing lives.

c. Listening to the recordings of the greatest pianists and musicians of the $20^{\text {th }}$ century should be encouraged. Students today tend to listen to too many performances of their pieces on video by adequate but unknown pianists in order to gain an idea of a work being learned. I find this to be a negative trend, as the artistry essential for meaningful interpretation and performances they will give - recitals, juries, concerts - can fall short of deeper musical content and communication.

d. In my own experience - having only entered two competitions in my teens and having been kept from any others on the advice of my major teacher, Munz, I do not believe that entering competitions is the optimum way to succeed in a career in music. On the positive side, all auditions, juries and competition with peers in life depend on the best preparation and hard work to do one's best, and the ability to take negative results and improve on them for the next life challenge, is of course, essential to grow and succeed.

e. From a young age, I would encourage families to emphasize healthy physical activity for their talented children, especially with an excessive use of the computer and endless sitting in addition to the pianist's necessity for sitting at the piano and practicing long hours. I like to describe each piano student as an athlete at their instruments, and that any strengthening and body exercise they can follow is a necessary counterreaction to our sedentary lives as pianists! Health is Number One.

f. Chamber music experience can add vast new musical dimensions for each piano student. This repertoire is huge and rich, and the opportunity to make music with peers and colleagues 
expands musicianship and depth of communication enormously. Under good coaching and guidance, learning to "get along musically" with each other is a life lesson worth its weight in gold!

\section{You are particularly associated with the works of Chopin and Schumann and with}

Rachmaninoff's Third Piano Concerto. What do you consider to be the quintessential qualities in performing each of these composers?

Fortunately, both Mrs. Gunn and Mieczysław Munz gave me many works of Chopin almost from my first lessons. Chopin, of course, creates the piano's most indigenous voice, and all pianists are nurtured and guided in producing his individual singing tone and his love for the Italian Bel Canto style in so many of his compositions. Mrs. Gunn gave me more than 16 of the Preludes, several Nocturnes, Mazurkas and Waltzes from my earliest lessons. In my first years with Munz at Peabody, he gave me right away the rest of the Preludes, all four Ballades, all four Scherzos, the Polonaise-Fantaisie, many Mazurkas, more Nocturnes and both Sonatas. He added the f minor Concerto, which I performed in Washington with the National Symphony when I was 15. In my lessons, Munz actually would dance some Mazurka steps to give me the feel and the swinging rubato of the dance, and specifically for the $3^{\text {rd }}$ movement. It has what I would call "a Mazurka within a Mazurka" in the A-flat section, together with a unique tapping of the wooden part of the violin bows giving the actual Mazurka rhythm accompanying the pianist's passages. Later in 1961, I was coached further in the Concerto by Arthur Rubinstein, who actually gave me the thrill of my life by accompanying me on the other of the two glorious Steinway B's in his Paris living room! When I finished the last movement, he said to me, "It is clear that you and I 
feel the Mazurka dancing in this movement!' It was also thanks to Rubinstein that I witnessed a true Polish Polonaise at a charity Polish Ball the Rubinsteins sponsored in New York City. They invited me in 1962 to the Ball, and I watched for the first time a true stately Polonaise danced, or walked, truly, with the Rubinsteins at the head of the couples. It was riveting. He was known so much for his great A-flat Polonaise, indeed playing it for the last time in New York after his farewell recital in Carnegie Hall, as the last encore. The great Polish Patriot in him, and in Chopin, saying goodbye to this devoted audience of so many years. But the stately, patriotic and proud walking stride of the true Polonaise was a new revelation.

Munz was the first to introduce me to the very personal world of Robert Schumann, assigning me, in his words, the more "intimate" of his compositions, the Humoreske and the Davidsbündlertänze. He added the A minor Concerto and the F-sharp minor Sonata, the opening bars of which he sat down and played with all his emotion and deep feeling. My heart stood still, as he never sat at the piano and played, having had to stop his performing career due to his hands and arms failing years before. In 1968, I played the Schumann Concerto in London at Albert Hall in a Promenade concert, with Colin Davis conducting. On this occasion, my future husband, Earl Carlyss, was there and heard me play for the first time. This made the occasion last forever in my memory! In England, the Schumann Concerto had been a signature piece of the beloved Dame Myra Hess, and audiences revered it especially.

It was Munz again who introduced me to Rachmaninoff's music, giving me several Études-Tableaux right away. He gave me several of the Preludes, and of course, he was the one who said to me one day at my lesson, "I am giving you a work you will never play now. It will be wonderful for expanding your technique and your stamina generally." He placed the score of 
the Third Concerto in front of me and started fingering the passages and the more difficult sections with his uncanny sense of what would produce greater ease and musical shape to the music. I spent a year working through its endless black notes on the page. As I have related to all who would listen, I remember the day he suddenly said, "How would you like to play this with the Peabody Orchestra?" How can one thank a teacher enough for all of this vision, exquisite sensitivity and belief in the future of their student's potential? A footnote: It was the recording of the Third Rachmaninoff I made along with the Chopin $\mathrm{f}$ minor in Vienna that was taken to Arthur Rubinstein in 1961, resulting in his wanting to meet the pianist whose performance had pleased him. There was always a deep feeling on my part for the great Russian soul and melancholy when I began to study Rachmaninoff's music. It came from deep inside the tonal and vocal beauty of the piano itself, and I almost felt as if I might have some Russian something in my DNA it was that close a feeling I felt for its voice. We also have many extraordinary recordings of Rachmaninoff to learn from and revel in. Munz knew Sergei Rachmaninoff personally and revered him personally and artistically.

\section{What do you enjoy most and least about teaching?}

I call teaching "People Work!" I love meeting people of all walks of life, and there is no end to the thrill and exhilaration of meeting and guiding each new person with musical talent entering the studio. It is an old truth, but the teacher and coach gain far more knowledge and musical revelation than the student by delving into the same repertoire with a new pair of hands, a completely different combination of emotions, ambitions, dreams and potential. The music can reveal itself in new ways, and each individual can express new inspirations and discoveries, 
astonishing and inspiring their teachers. Great music can come across in so many, many ways. The discouragement comes in our current days, with an excess of technological distractions and the necessity of working digitally and virtually so many hours of the day. The great artists of the $20^{\text {th }}$ century that we heard and learned from are gone, and although great recordings are available, the live concert experience is receding in today's world. Life happens too fast, and a too superficial amount of knowledge too quickly gained leads to performances that are only partially satisfying musically. Our world of entertainment can be alluring, and this can lead to careers that come to some fame and reputation too early, even if audiences react to their momentary excitement - encouraging this level of brilliant execution to seem like enough achievement. We can concentrate on guiding students to develop more patience and more knowledge and hope that this will influence each of them to persevere in bringing their talent to deeper artistic fruition for many more years.

\section{What is your daily practice routine like? Does it change on concert days or days leading up}

\section{to a concert?}

For me, there might be three categories in answering this question. From my own professional debut at 17 to my 30 's, I practiced 6-8 hours daily in a regular routine. When I had a performance, I kept this schedule up through the day before a concert. On a concert day, I only did three hours on the piano in the hall from about 10 to 1, then ate a big meal and hopefully, slept a few hours. I then had a light snack, and that would carry me until after the concert, when I loved being with friends and family and going out to eat something delicious at night! 
Age 30-50 - marriage, children and performances, a new combination of challenges, needing improvisation of time and energy, more concentrated practice routines and flexibility in arranging time and schedules for enough practice to keep the repertoire at its best level.

Teaching plus performing, the most daunting challenge. How to organize the hours with less exhaustion for practicing? I finally decided that I could teach long days until dinner time, and be totally worn out, which I definitely was, but after eating, I could practice late into the night, as I was never tired-out by practicing! Many times, due to the demands of growing children and a travelling husband, my own performances often fell short of the best result, due to inadequate practice time and proper concentration. Somehow, one goes on despite these disappointments in order to keep growing as a musician. We each figure it out in our own way! In Polish, there is a saying: "Never give up!" I saw this in the lives and souls of both Munz and Rubinstein powerful role-models.

\section{What do you consider to be the most essential qualities for a successful musician to have?}

Good health, optimistic spirit, curiosity for music and life in general, a good feeling for communicating music to the audience in a fresh and spontaneous way, and the courage to face adversity, failure and life's shocks with courage and hope. The life of a travelling and performing musician is more demanding than one foresees in student years, and the teachers can do much to prepare a gifted young talent for this reality in their future. The rewards of great music-making are so wonderful, that all efforts are worth it! Building good relationships is also a help in the increasingly isolated world we live in today. We need a Team of Support as solo pianists, whoever this may be - friends, family, partners, mentors. I emphasize this strongly. 


\section{In what way, if any, has your faith influenced your career?}

My parents gave me the priceless gift of their faith in God's Love and protection from my earliest years. I never sensed their own fears for me in any way, or their anxieties for my future. When I met my husband-to-be in 1966, it was his faith and calm strength that acted like a magnet for me, as it seemed the continuation of my parents' gift to me. Earl's father was a minister and he had led his family "By Faith," as he named a book he wrote about his life. Prayer before and during a performance has been my companion in all my performing years and has sustained me through every circumstance. When I have fallen and failed, so many times, God has mercifully picked me up and encouraged me to go forward, and to make me an instrument through which the music flows. Hopefully, this has communicated to my students in some unspoken way and has given them more courage to pursue their own artistic and musical dreams and goals. ${ }^{118}$

118 Ann Schein, emails to author, February 7 and 13, 2021. 


\section{CHAPTER IV}

\section{INTERVIEWS WITH STUDENTS OF ANN SCHEIN}

Schein has said that "it's our obligation to pass on the great things we have learned from our teachers."119 She has faithfully fulfilled this obligation not only through positions at the Peabody Institute, the Aspen Music Festival and School, Indiana University, the Eastman School of Music, Stony Brook University and the Mannes School of Music, but also through countless masterclasses and residencies at universities both nationally and internationally. Included here are photographs, biographies and interviews with six of Schein's former students who studied with her at the Peabody Institute. These interviews were conducted by email with the author and are intended to provide a pedagogical record of Schein's teaching as well as a testament to her influence and impact, both directly on and then continued through her students.

119 Litzelman, 31. 


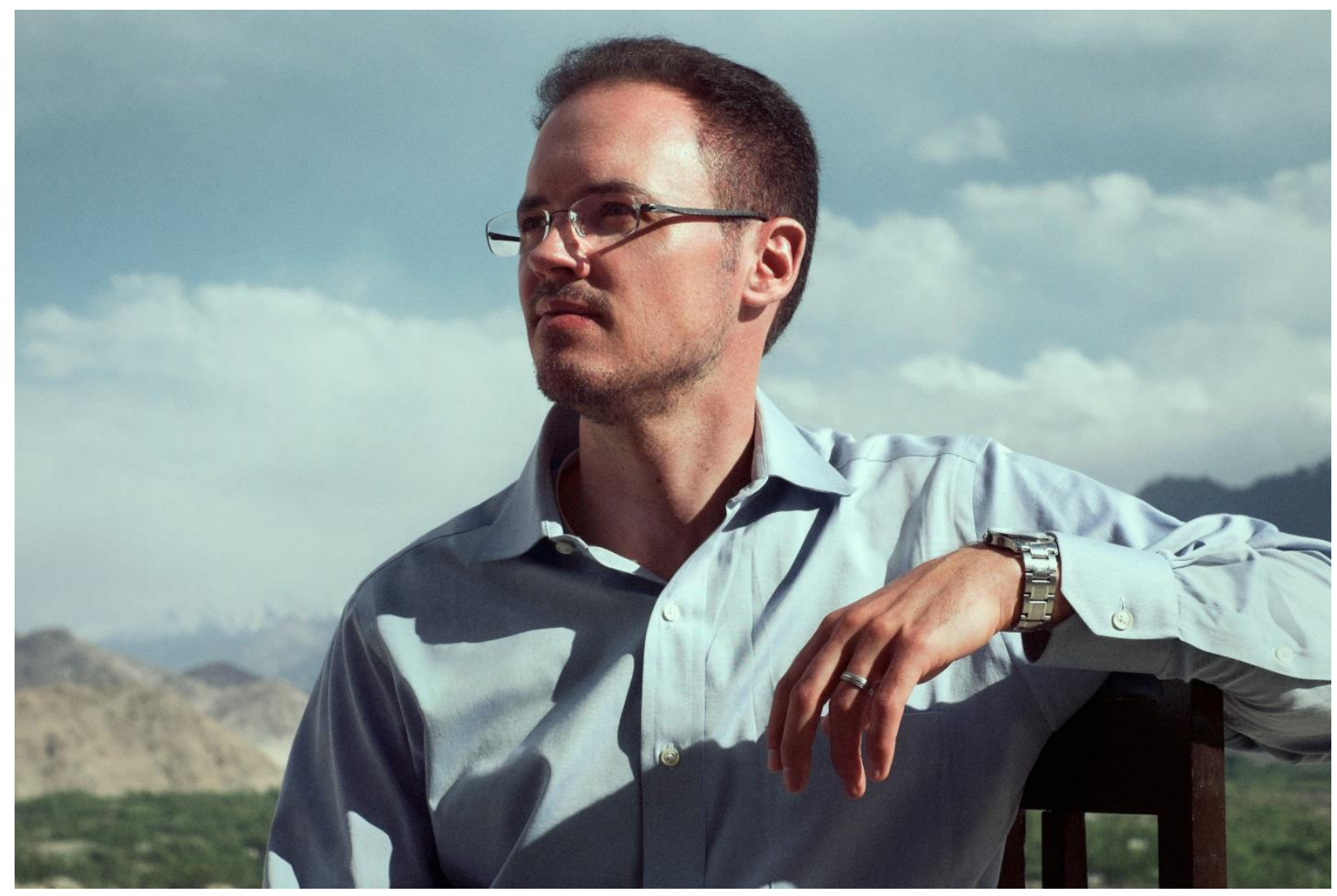

Figure 4.1 Photograph of Matthew Bengtson ${ }^{120}$

Critically acclaimed as a "musician's pianist," Matthew Bengtson has a unique combination of musical talents ranging from extraordinary pianist, to composer, analyst, writer, scholar of performance practice, and educator. An advocate of both contemporary and rarely performed music, he offers a diverse repertoire, ranging from William Byrd to György Ligeti and numerous contemporary composers. He has performed concerts as both soloist and collaborator in France, Germany, Italy, Poland, and Hungary, in Mexico, in Washington, DC, at Monticello,

${ }^{120}$ Photograph provided by Matthew Bengtson, email to author, November 22, 2020. Photo Credit Jarek Kotomski. 
and in solo recitals at Carnegie Hall's Weill Recital Hall. He has been heard with violinist Joshua Bell on NPR's "Performance Today" and XM Satellite Radio's “Classical Confidential." His recordings can be heard on the Roméo, Arabesque, Griffin Renaissance, Albany, Navona, and Musica Omnia record labels.

Mr. Bengtson is lauded as one of the most persuasive advocates of the music of Scriabin and Szymanowski. On his complete Scriabin Piano Sonatas, the American Record Guide writes: "Big-boned pianism, rich tonal colors, and dazzling technique are on display here. Has Scriabin ever been played better? Only Horowitz and Richter can compare.” Fanfare magazine calls him "a Scriabinist for the $21^{\text {st }}$ century ... upon whom future generations can rely for definitive interpretations.” In 2015, he toured with the complete Scriabin sonatas, and performed in the historic centennial "Scriabin in the Himalayas" festival in Ladakh, India. He is a co-author of “The Alexander Scriabin Companion: History, Performance, and Lore” published by Rowman and Littlefield Press.

Equally devoted to the music of Karol Szymanowski, he has recorded a 3-CD recording of the solo piano and violin/piano duo music of the great Polish composer, together with violinist Blanka Bednarz, on the Musica Omnia label, again to critical acclaim. The duo has presented numerous all-Szymanowski duo/solo recitals across the United States, and in Poland, including the Karol Szymanowski Museum in Zakopane. His analytical paper on Szymanowski mazurkas won a Stefan and Wanda Wilk Prize for Research in Polish Music and is published in the Canadian music journal "Intersections." Other notable collaborations include the "Sierra Duo" with cellist John Haines-Eitzen, with whom he recorded the complete cello and piano music of Roberto Sierra for Albany Records. 
Mr. Bengtson is among today's proponents of historical performance practice, preferring to perform music when possible on instruments from the era of the composer. Old-style performing techniques he has put to use in his performances include improvised modulating preludes, ornamented reprises, and original cadenzas. He studied harpsichord with Webb Wiggins at Peabody, and fortepiano with Malcolm Bilson at Cornell University. His video introduction to the Viennese 5-octave fortepiano has become a YouTube favorite. He has recorded on fortepiano and harpsichord for Arabesque Recordings and has given presentations and performances at the Historical Keyboard Society of North America and the Westfield Center for Historical Keyboard Studies, among others. He teaches in the annual summer program University of Michigan Early Keyboard Institute (UMEKI). His students took the top prizes at the inaugural sfzp International Fortepiano Competition in New York.

Mr. Bengtson is Assistant Professor of Piano Literature at the University of Michigan School of Music, Theatre and Dance, where he teaches piano and fortepiano, and courses and seminars in piano repertoire, history and culture. He has taught at the University of Pennsylvania, at Haverford and Bryn Mawr Colleges, at Carnegie Mellon University's School of Music, and the Peabody Institute, and served on the collaborative piano staff at the Curtis Institute of Music. Besides his musical attainments, Mr. Bengtson was educated at Harvard University with a focus in mathematics and computer science. Mr. Bengtson is a Steinway Artist. ${ }^{121}$

${ }^{121}$ Biography provided by Matthew Bengtson, email to author, January 20, 2021. 


\section{When and where did you study with Ann Schein?}

Peabody, MM 1996-97, DMA 1997-2001. Aspen, 1997.

\section{What repertoire did you study with Ann Schein?}

Bach: The Well-Tempered Clavier, Book I, numerous Preludes and Fugues

Rameau: Suite in A Minor, RCT 5 from Nouvelles Suite de Pièces de Clavecin (Allemande, Courante and Gavotte with Doubles)

Haydn: Sonata in C Major, Hob. XVI:50

Beethoven: Violin Sonata in C Minor, Op. 30, No. 2; Sonata in F-sharp Major, Op. 78; Sonata in A Major, Op. 101

Schubert: Sonata in A Minor, D. 784; Impromptus, D. 899, Nos. 3 and 4

Schumann: Davidsbündlertänze, Op. 6; Violin Sonata in A Minor, Op. 105

Chopin: Nocturne in D-flat Major, Op. 27, No. 2

Liszt: Transcendental Étude in E-flat Major; Totentanz

Brahms: Piano Trio in C Minor, Op. 101

Fauré: Violin Sonata No. 1 in A Major, Op. 13

Franck: Violin Sonata in A Major

Debussy: Études, Book Two (complete)

Scriabin: Sonata No. 4 in F-sharp Major, Op. 30; Sonata No. 8, Op. 66; 3 Mazurkas from Op. 25; Concerto in F-sharp Minor, Op. 20

Prokofiev: Sonata No. 2 in D Minor, Op. 14

Rachmaninoff: Concerto No. 3 in D minor, Op. 30 
Szymanowski: Mazurkas from Op. 50 (numerous) and Op. 62; "Schéhérazade" from Masques,

Op. 34; Étude in E-flat Minor, Op. 4, No. 1; Myths, Op. 30

Bartók: Out of Doors

Schoenberg: Drei Klavierstücke, Op. 11

Boulez: Sonata No. 1

Ligeti: Études: “Touches Bloquées," “Arc-en-ciel," “En suspens,” "Der Zauberlehrling”

\section{What do you consider the most important things you learned from Ann Schein that you use in your playing and/or teaching today?}

I think I would say it's a much greater awareness of piano sound - a major theme in much of her teaching - and the physical approach to varying it. Better ability to adapt to instruments and acoustics. All practical matters, so I have become more confident and secure in performance. A greater appreciation for the strength of rhythm, in a variety of contexts, including accompaniments, and ways to think about organizing rhythm on different levels.

\section{How would you describe the approach to piano technique that Ann Schein taught?}

It's not easy to generalize. She was never dogmatic but had a wide variety of approaches for particular circumstances. Fingering was important. Solidity of position and firmness of intent was also important; she was never a fan of approximations, and I would surely get chided if I didn't play well into the keybed. She would often put "accents" in surprising places, more than I'd have thought possible, but the approach to the technique often gave the music a lot more vividness, precision, and rhythmic life; a really good example of that was in the extremely rapid 
Coda of the Scriabin Eighth Sonata. I know she had a wide repertoire of practicing devices and I regret that I didn't probe into these more specifically. I remember a really useful "doubling-up"

practicing method (pattern $\mathrm{ABC}$ becomes $\mathrm{AABBCC}$ ), for instance, in Rachmaninov $3^{\text {rd }}$ Concerto that helped to solve the double-note passage at the end of the first movement. In the chordal passage in the final movement, she advocated a certain kind of full-body approach that organized the entire motion, making it flow in a more athletic motion. I got a similar kind of effective advice in the Liszt E-flat Transcendental Étude. She often credited her teacher Mieczysław Munz for these kinds of ideas.

\section{How would you describe the approach to interpretation that Ann Schein taught?}

This isn't easy to generalize at all, but I think she took each particular case on its own merits. She was never dogmatic or belonging to one particular school of playing, but always encouraged people to expand their musical vistas through listening and reading. Her interpretation was an intuitive mixture of approaches taken from many different sources and of course her own rich experience as a performer and student of greats.

She did consistently emphasize a kind of listening that required a detailed awareness of voice-leading. It seemed like a kind of Schenkerian approach, isolating certain pitches and following their movements both within and across registers. I think the result of this method, when fully applied, was a fullness of harmony and a continuity of sound over longer stretches, leading to more coherent playing. 


\section{Did Ann Schein teach you any practice skills or daily routines to follow?}

Not many specific ones, although again it would have been interesting to probe this further, to learn both as a player and a teacher. She did give Schumann's advice that the Bach WTC should be daily bread, and I took that very seriously in this period! It was meaningful work for many reasons beyond the value of the repertoire itself.

\section{Is there anything else you would like to add about your studies with Ann Schein?}

She lived with Earl Carlyss, a string player, and was surrounded by other musicians. She talked about Beethoven quartets a lot. She was always interested in the broader scope of the repertoire, beyond solo music, and knew the qualities of other instruments and how they mix. My violinist partner spoke very highly of her understanding of her instrument's sound. Among numerous performances of hers that I heard, one that stood out to me was her Brahms B-flat Concerto. I know it was a piece she played for the first time, and not at an early age. Even though she professed to have difficulties in communication with the conductor and the group, it was a remarkably polished performance of a really difficult piece! ${ }^{122}$

122 Matthew Bengtson, email to author, November 22, 2020. 


\section{Ya-Ting Chang}

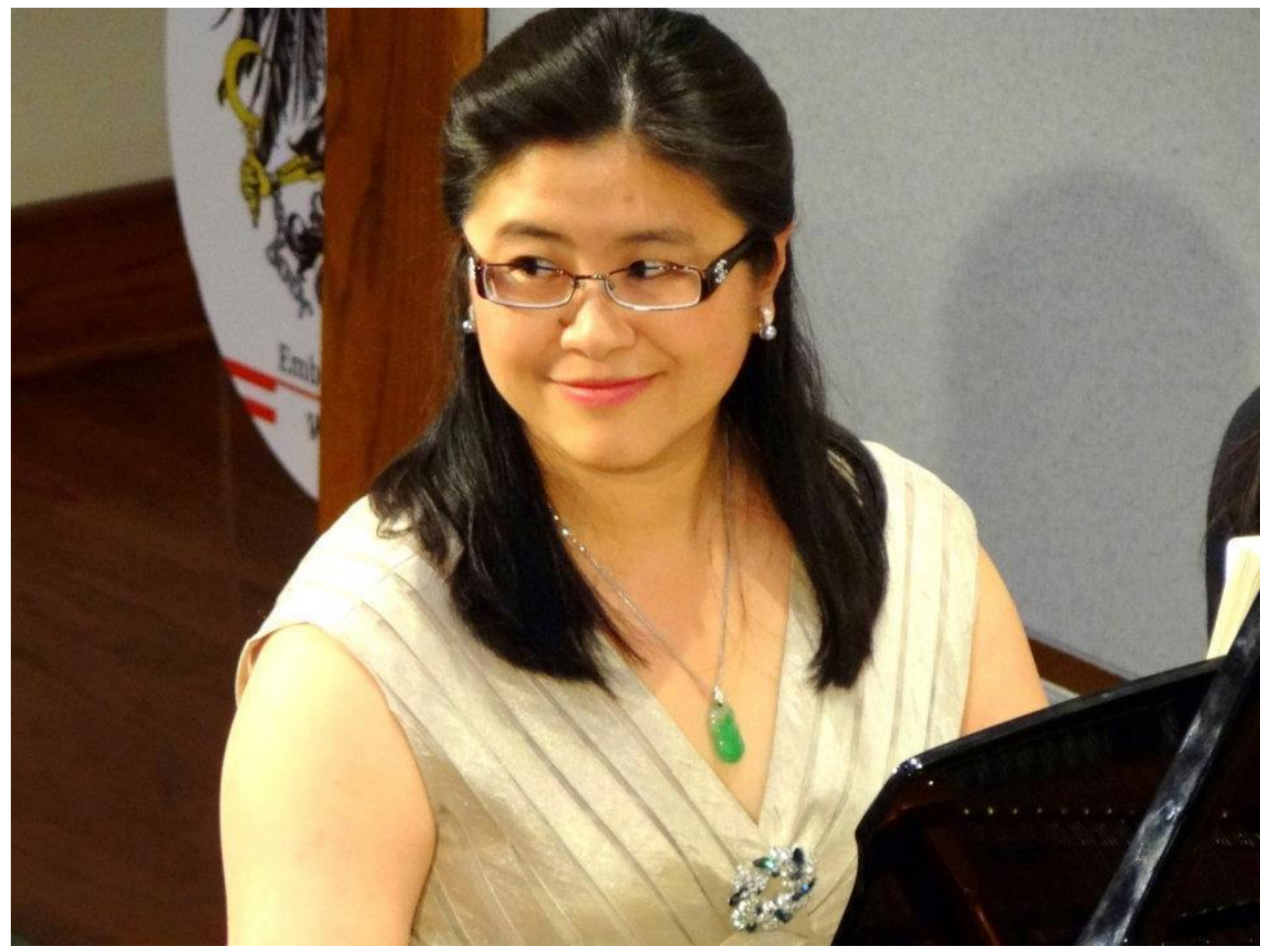

Figure 4.2 Photograph of Ya-Ting Chang ${ }^{123}$

Taiwanese-American pianist Ya-Ting Chang is the Director of Market Square Concerts in Harrisburg, Pennsylvania, and a member of the piano faculty at Messiah University in Mechanicsburg, Pennsylvania.

Chang came to the United States in 1988. She studied with Enrique Graf (a pupil of Leon Fleisher) and Ann Schein (a pupil of Mieczysław Munz, Arthur Rubinstein and Myra Hess.)

123 Photograph provided by Ya-Ting Chang, email to author, December 29, 2020. 
Chang has performed extensively throughout the United States, Germany, Hong Kong and Taiwan. For three years she participated in the Collaborative Artist Program at the Aspen Summer Festival and performed in the International Piccolo Spoleto Music Festival in Charleston, South Carolina. Chang appeared as a soloist with the Messiah College Orchestra, Gettysburg Chamber Orchestra, Shippensburg University Festival Orchestra as well as the Hong Kong Chamber Orchestra. She has given masterclasses and served as an adjudicator in competitions. She has collaborated with pianist/conductor Stuart Malina, oboist Gerard Reuter, bassoonist Peter Kolkay, members of Baltimore Symphony, National Symphony, Memphis Symphony and Harrisburg Symphony orchestras, as well as renowned cellist Ronald Leonard, with whom she recorded a $\mathrm{CD}$ of cello sonatas by Grieg and Dohnanyi.

In 1997 Ms. Chang, together with her husband, violinist Peter Sirotin, co-founded the Mendelssohn Piano Trio. With this group she has performed over 500 concerts in US, Europe and Asia and recorded $15 \mathrm{CDs}$ including most recently the complete Haydn Piano Trios on Centaur Records.

In 2012, Ya-Ting Chang appeared as a soloist in the world premiere of Ching-Ju Shih's Double Concerto for Violin, Piano and Orchestra at the National Concert Hall in Taipei, Taiwan. Recently, she has appeared as a soloist with the Harrisburg Symphony and Gettysburg Chamber Orchestra. ${ }^{124}$

124 Biography provided by Ya-Ting Chang, email to author, December 29, 2020. 


\section{When and where did you study with Ann Schein?}

1990 One piano masterclass (I don't remember the date)

Spring 1991 - 1992 Peabody Preparatory / Privately

1992 - 1998 Peabody Institute of the Johns Hopkins University (Bachelor and Master in

Piano Performance) \& 3 summers at the Aspen Music Festival and School

My initial encounter with Ms. Schein was in a piano masterclass which was hosted by

Peabody Preparatory sometime during the 1990-91 academic year. I was studying with Enrique

Graf at the time at the Peabody Preparatory, and was given the opportunity to participate in the masterclass. I learned a lot from that one session. Shortly after that, Mr. Graf had relocated to South Carolina for a full-time professorship at another institution. I had such a revelation from the masterclass with Ann Schein that my mother (with the help of the Peabody Preparatory Dean, Fran G. Zarubick and Mr. Graf) contacted Ms. Schein to see whether I could have a trial lesson with her and hopefully accept me as her student even though I still had more than a year left in the preparatory. She accepted me as her student, and we started our journey in the Spring of 1991.

\section{What repertoire did you study with Ann Schein?}

Most, but not all, repertoire listed below was performed publicly either in studio classes, masterclasses, or recitals/performances during the time I studied with Ms. Schein. Due to the large quantity of pieces, please note that this list might be incomplete or with minor errors. There might be a few pieces included below that I might have studied with previous teachers which I marked (unsure). 
Albéniz: "Evocation" from Iberia, Book I

Bach: Partita No. 1 in B-flat Major, BWV 825; Partita No. 2 in C Minor, BWV 826; The WellTempered Clavier, Book I (Prelude \& Fugue 2 in C Minor, Prelude \& Fugue 3 in C\# Major, Prelude \& Fugue 8 in E-flat Minor, Prelude \& Fugue 15 in G Major, Prelude \& Fugue 17 in A-flat Major, Prelude \& Fugue 22 in B-flat Minor, Prelude \& Fugue 23 in B Major); The Well-Tempered Clavier, Book II (Prelude \& Fugue 2 in C Minor, Prelude \& Fugue 16 in G Minor, Prelude \& Fugue 17 in A-flat Major); (Bach/Busoni) Chromatic Fantasia and Fugue

Bartók: Improvisations, Op. 20

Beethoven: Sonata No. 1 in F Minor, Op. 2, No. 1 (unsure); Sonata No. 6 in F Major, Op. 10, No. 2; Sonata No. 12 in A-flat Major, Op. 26; Sonata No. 18 in E-flat Major, Op. 31, No. 3; Sonata No. 27 in E Minor, Op. 90; Sonata No. 28 in A Major, Op. 101; "Eroica" Variations and Fugue in E-flat Major, Op. 35; Piano Concerto No. 3 in C Minor, Op. 37; Piano Concerto No. 5 in E-flat Major, Op. 73

Brahms: Scherzo in E-flat Minor, Op. 4; Sechs Klavierstücke, Op. 118 Chopin: Ballade No. 1 in G Minor, Op. 23; Ballade No. 4 in F Minor, Op. 52; Études Op. 10, Nos. 1, 2, 3, 4, 5, 6, 8, 10 \& 11; Études Op. 25, Nos. 3, 4, 9, 10 \& 12; Impromptu No. 1, Op. 29; Impromptu No. 2, Op. 36; Impromptu No. 3, Op. 51; Mazurkas, Op. 6, No. 1 in F-sharp Minor; Mazurkas, Op. 50, No. 1 in G Major; Mazurkas, Op. 50, No. 2 in A-flat Major; Mazurkas, Op. 50, No. 3 in C-sharp Minor; Polonaise Op. 53 in A-flat major; Scherzo No. 1, Op. 20 in B Minor; Barcarolle in F-sharp Major, Op. 60; Sonata No. 2 in 
B-flat Minor, Op. 35; Sonata No. 3 in B Minor, Op. 58; Concerto No. 1 in E Minor, Op. 11

Copland: Piano Variations (1930)

Debussy: Estampes, L. 108; Images, Book II ("Et la lune descend sur le temple qui fut," “Poissons d'or”); Étude No. 5 pour les octaves; Étude No. 11 pour les arpèges composes; Preludes, Book I (No. 10 "La cathédrale engloutie"); Preludes, Book II (No. 4 "Les fées sont d'exquises danseuses")

Haydn: Sonata in C Major (for senior recital); Andante with Variations in F Minor, Hob. XVII:6 (unsure)

Wolfgang Amadeus Mozart (1756-1791) - Sonata in A Minor, K. 310;

Sonata in C Major, K. 330; Sonata in C Minor, K. 457; Sonata in D Major, K. 576; Concerto No. 13 in C Major, K. 415 (unsure)

Mussorgsky: Pictures at an Exhibition

George Perle: Sonatina

Rachmaninoff: Transcription of the Scherzo from F. Mendelssohn “A Midsummer Night's Dream;” Transcription of F. Kreisler “Liebesleid;” Études-Tableaux, Op. 33, No. 2; Études-Tableaux, Op. 39, No. 1

Ravel: Pavane pour une infante défunte; Sonatine; Miroirs (III. “Une barque sur l'ocean,” IV. “Alborada del gracioso"); Gaspard de la nuit

Saint-Saëns: Allegro appassionato, Op. 70 (1874)

Schoenberg: Drei Klavierstücke, Op. 11 (1909) 
Scarlatti: Selected Piano Sonatas (I studied four with her in Aspen, but it has been such a long time that I don't remember which four.)

Schubert: Impromptus, Op. 90, No. 1; Sonata in A Major, D 959

Schumann: Papillons, Op. 2; Carnaval, Op. 9; Sonata No. 3 in F Minor, Op. 14

Gerard Schumann: Two Ballades for Piano (I. "Hukvaldy,” II. “Brno”)

Augusta Read Thomas: "Whites” for Solo Piano (1988)

\section{What do you consider the most important things you learned from Ann Schein that you use in your playing and/or teaching today?}

a. Commitment to an open-ended and open-minded inquiry into the composers' intentions, background, history and context for every piece of music I am teaching or performing.

b. Understanding the evolving nature of one's relationship with the music over time, as well as the idea that every time a piece of music is performed it is co-created by a performer and composer as a fresh work of art.

c. Realizing that compelling performances happen when we sincerely try to communicate with the audience in the moment, rather than trying to recreate the most accurate version of a performance from a practice session or a dress rehearsal.

d. As a great performer, she offered rich learning opportunities through her live performances, as well as by letting me turn pages during rehearsals, performances and recordings.

e. Above all, the depth of her listening, as a shining example of a direct path toward growth and authentic musical insight, continues to be an inspiration. 


\section{How would you describe the approach to piano technique that Ann Schein taught?}

Highly varied from individual to individual. The few overarching themes include strengthening the body for efficient movements, developing individual finger independence and creating your own exercises. Learning to adopt to different instruments and successfully communicate musical intention under different acoustical conditions. In sound production, she emphasized going beyond the piano for reference, drawing on vocal, string quartet, and orchestral analogies for timbre, shaping, form, texture, and voicing.

\section{How would you describe the approach to interpretation that Ann Schein taught?}

While I have touched on this a little in my answer to your third question, I want to add that Ms. Schein's approach to interpretation in teaching emphasizes depth of engagement with the score and the composer as a living individual behind it. She is unusually sensitive to each student's strengths and weaknesses, drawing out of them the most authentic personal interpretation of the music they are working on. Rather than simply offering critical feedback, she tends to engage in a dialogue, inviting students to consider their choices from multiple perspectives on a deeper level, which leads students to develop authentic interpretations, grounded in a critical reflection.

\section{Did Ann Schein teach you any practice skills or daily routines to follow?}

Yes. Creating your own exercises to solve technical problems: rhythm work, scales, arpeggios, études... etc. Most importantly, tackling tasks when they arise, identifying and solving problems. One of the more important practice skills that I try to pass on to my students as 
well, is working toward a range of possibilities rather than toward a specific outcome, in order to be prepared for performing conditions that are always changing.

\section{Is there anything else you would like to add about your studies with Ann Schein?}

I just want to add that beyond her tremendous artistry and paradigm-shifting mentorship, Ms. Schein's kindness, generosity, compassion and warmth profoundly touch everyone who had the privilege to work with her. Twenty-five years after my graduating from Peabody, she remains one of the greatest human beings and artists I have ever known. ${ }^{125}$

125 Ya-Ting Chang, email to author, December 29, 2020. 


\section{Inna Faliks}

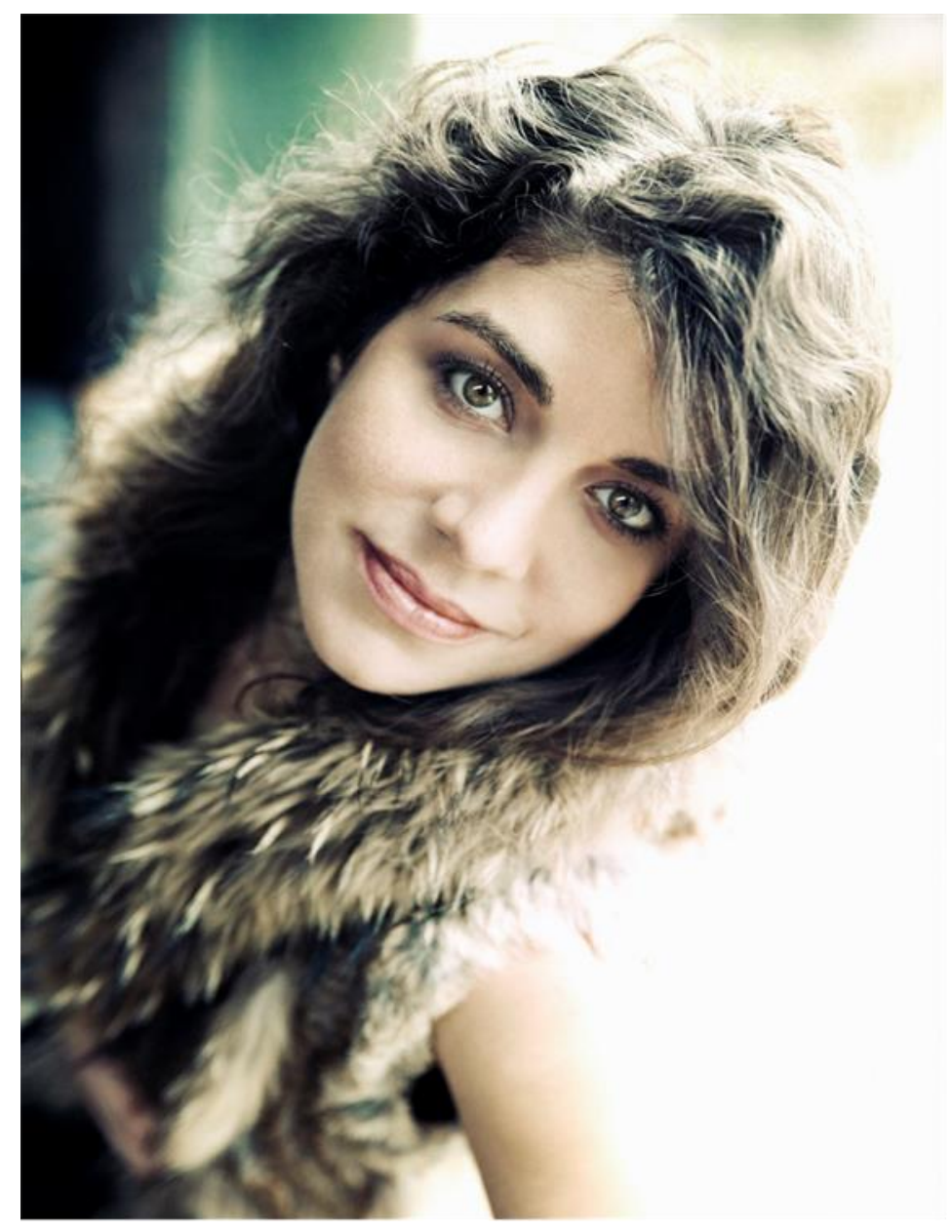

Figure 4.3 Photograph of Inna Faliks ${ }^{126}$

"Adventurous and passionate" (The New Yorker) Ukrainian-born American pianist Inna Faliks has made a name for herself through her commanding performances of standard piano repertoire, as well genre-bending interdisciplinary projects, and inquisitive work with contemporary composers. After her acclaimed teenage debuts at the Gilmore Festival and with the Chicago Symphony Orchestra, she has performed on many of the world's great stages, with

${ }^{126}$ Photograph taken from innafaliks.com (accessed January 8, 2021). 
numerous orchestras and in solo appearances. Faliks is currently Professor of Piano and Head of Piano at UCLA. Critics praise her "courage to take risks, expressive intensity and technical perfection" (General Anzeiger, Bonn), "remarkable insight" (Audiophile audition) "poetry and panoramic vision" (Washington Post), "riveting passion, playfulness" (Baltimore Sun) and "signature blend of lithe grace and raw power" (Lucid Culture.) Her October 2014 all-Beethoven CD release on MSR classics drew rave reviews: the disc's preview on WTTW called Faliks "High priestess of the piano, concert pianist of the highest order, as dramatic and subtle as a great stage actor." Her previous, critically acclaimed CD on MSR Classics, Sound of Verse, was released in 2009, featuring music of Boris Pasternak, Rachmaninoff and Ravel. Her discography also includes a recital recording for the Yamaha Disklavier label, Chopin solo and cello sonatas recording with cellist Wendy Warner, "Polonaise-Fantasie, Story of a Pianist" for Delos - an autobiographical monologue-recital of short piano works from Bach and Chopin to Gershwin and Carter. Highlights of the recent seasons include performances in Ravinia Festival and the National Gallery in DC, recital tours of China, with appearances in all the major halls such as Beijing Center for Performing Arts, Shanghai Oriental Arts Theater and Tianjin Grand Theater, as well as acclaimed performances at the Festival Intenacional de Piano in Mexico, in the Fazioli Series in Italy and in Israel's Tel Aviv Museum, at Portland Piano Festival and with the Camerata Pacifica, with the modern dance troupe Bodytraffic at the Broad Stage Santa Monica, and Jacaranda Series in Los Angeles, where she performed Rzewski's The People United Will Never Be Defeated. Faliks has been featured on WQXR, WNYC, WFMT and many international television broadcasts, and has performed in many other major venues, such as Carnegie Hall's Weill Concert Hall, Metropolitan Museum of Art, Paris' Salle Cortot, Chicago's Symphony 
Center, Moscow's Tchaikovsky Hall and in many important festivals such as Verbier, Newport, Portland International, Music in the Mountains, Mondo Musica Cremona, Brevard, Taos, International Keyboard Festival in NYC, Bargemusic, and Chautauqua. She is regularly engaged as a concerto soloist nation-wide.

Faliks is the founder and curator of the of the Manhattan Arts Council award winning poetry-music series Music/Words, creating performances in collaboration with distinguished poets. This has been described as "surreal, impactful, and relevant" (Lucid Culture). Her longstanding relationship with WFMT radio has led to multiple broadcasts of Music/Words, which she had produced alongside some of the nation's most recognized poets in performances throughout the United States. An artist known for her versatility, Faliks is equally at home with standard repertoire, rare and new music, and interdisciplinary performances. She recently costarred with Downton Abbey star Lesley Nicol in "Admission - One Shilling," a play for pianist and actor about the life of Dame Myra Hess, the great British pianist. Most recently, she is touring with her autobiographical recital-monologue, "Polonaise-Fantasie, the Story of a Pianist" throughout the US and Canada. Constantly in dialogue with today's composers, she has had works composed for her by Timo Andres, Billy Childs, Richard Danielpour, Paola Prestini, Ljova, Clarice Assad, Peter Golub, and many more. She was the winner of many prestigious competitions, including Hilton Head International Piano Competition and International Pro Musicis Award.

Faliks is internationally in demand as an Artist Teacher, and frequently adjudicates competitions gives masterclasses and travels to Artist Residencies in major conservatories and universities around the world. In March 2019, Faliks was Artistic Director of Classical Music for 
YoungArts LA, programming and workshopping a program with the nation's top young musicians and composers, as well as directing a number of panels and masterclasses. As a writer, she has been published by LA Times and Washington Post.

Inna Faliks is a Yamaha Artist. ${ }^{127}$

\section{When and where did you study with Ann Schein?}

I studied with Ann Schein at Peabody Conservatory during my undergraduate degree (1997-2000, I think, give or take a year).

\section{What repertoire did you study with Ann Schein?}

We studied a lot of works. I had already won a few important competitions and was touring and performing and competing, during my studies with her, so my repertoire was already quite large at that time. Some of my most important pieces of my life I had first worked on with her and have since recorded and performed them hundreds of times. This is certainly a testament to her, to how she made me feel while learning these pieces, how these pieces felt as I was learning them and beginning a life's journey with them. These include: Polonaise-Fantasie, Op. 61 of Chopin, which is the centerpiece of my monologue-recital performance piece and CD Polonaise Fantasie: The Story of a Pianist, Brahms' Sonata in F Minor, Op. 5 (I had never played any Brahms until I came to her, at age 18 . She already knew my personality as a pianist, my style, etc., and confidently assigned me this gigantic work. It became one of my most important works, one which I have performed countlessly. She knew so well what fit a particular

${ }^{127}$ Biography provided by Inna Faliks, email to author, January 8, 2021. 
student), Beethoven's Third and Fourth concerti, hours of music of Chopin, in addition to the Polonaise Fantasie, Beethoven's Bagatelles, Op. 126, Beethoven’s Op. 111, Scriabin’s Fifth Sonata, Schumann's Symphonic Études, Op. 13 (one of my mother's favorite pieces, and also one of my big works that I play a lot), Corigliano's Fantasia on an Ostinato, and the PaganiniRhapsody of Rachmaninoff (how I wish I studied Rachmaninoff 3 with her).

\section{What do you consider the most important things you learned from Ann Schein that you use in your playing and/or teaching today?}

It is very hard to quantify just how profoundly grateful I am to have had her as a teacher, mentor, beloved friend. There are so many ways in which she influenced me - not just pianistically but as a human being. Her wisdom and depth, as an artist and human, came out in every word she spoke. Her teaching was not literal, (so, not "play this passage like this, softer here, louder here) - she did not spoon feed. She made you think and feel deeply, search in your emotional vocabulary, find a truth, remain as honest as possible. She has her own instantly recognizable sound at the piano. She possesses a rare ability to recognize personality, individuality in a student, and treasure it and help develop it. When I came to her, I had my own sound. She gave me the confidence to believe in it and to recognize it. She opened my eyes in many ways, drawing many connections between piano music and other works of a given composer. She helped find the most immediate and direct way to deliver a performance, helped 
me find a bird's eye view of a piece, taught me to deliver it with confidence and nobility and simplicity. Even now, when I think of her, I think of playing with nobility, honesty, directness, beauty, principled rhythm.

Her teaching in every way mirrors her artistry at the piano.

\section{How would you describe the approach to piano technique that Ann Schein taught?}

I cannot separate technique and music making. Ann Schein taught every student differently, as every student needs technical guidance in line with their experience and level. I do think that my position at the piano changed, when I was with her. I sat up taller, sat higher, moved around less, did things with more simplicity. She is not a tall person nor does she have an enormous hand but her regal way at the piano solved many technical challenges the score may present just with economy of motion and the solid feeling of being centered.

\section{How would you describe the approach to interpretation that Ann Schein taught?}

Elegance, rhythmic straightforwardness, honesty, depth of feeling, sound that is a personal voice, connections to other works by the composer and of the time period - coherence of structure and a bird's eye view of a work. Poetry, directness. Nobility of this art form. Taste.

\section{Did Ann Schein teach you any practice skills or daily routines to follow?}

Please see \# 3...It is hard for me to describe anything about Ann Schein as "routine." I had already a very strict sense of discipline when I came to Peabody. I practiced 8 hours a day. What we did together wasn't really about that, I think. But she inspired me so profoundly that discipline only increased. 


\section{Is there anything else you would like to add about your studies with Ann Schein?}

She was like a mom to me when I was at Peabody. We were close on a different level than student and teacher. Some of her wisdom took me years to absorb and understand. There are so many precious memories. She had once given me a dark blue velvet dress which she herself had worn to her performances. We had gone to get it altered, together, and had cake afterwards. It's such a bright memory - and I wear the dress still, to concerto performances. In fact, when I went to play a concerto after the birth of my daughter, Tchaikovsky 1 (my first trip after giving birth 1.5 months before), I wore it and thought of her, of how she played on and on, between giving birth to two daughters.

She had been so wise, so giving and generous. I was a teenager, 18, when I came to her and I feel that I had not adequately appreciated or realized what a treasure she is, when I was her student. We were more than teacher and student - she taught me lessons about a life in music which I still think about. She inspired me so much, the twinkle and fire in her eyes, her elegance, her beautiful, poetic, wise way with words and with making music.

After my studies with her, I frequently called her for advice - and I realize now, how generous she is and was, to share her own experience, stories, advice with me so openly. I didn't think, back then, about the fact that she was taking time from her own practicing, her own family and daily life, etc. to enter the world of one of her many students and give deep and heartfelt advice. I think that many of her students will have had this experience - her generosity of spirit knows no bounds.

She gave me such confidence in my own voice - I really know of no other teacher who has that gift, at such a level. As a teacher, now, I think about this often. The most important thing for 
a young artist is to believe in themselves, in the story they tell through the music - and a great artist teacher recognizes this and helps this process mature.

When I hear her sound, still, I tear up. It is a rarity that a sound so powerfully communicates the essence of not only the music and the composer but of the performer; this is a gift of a great artist that is rare to find, today. I am so fortunate to have her in my life. ${ }^{128}$

${ }^{128}$ Inna Faliks, email to author, January 8, 2021. 


\section{Li-shan Hung}

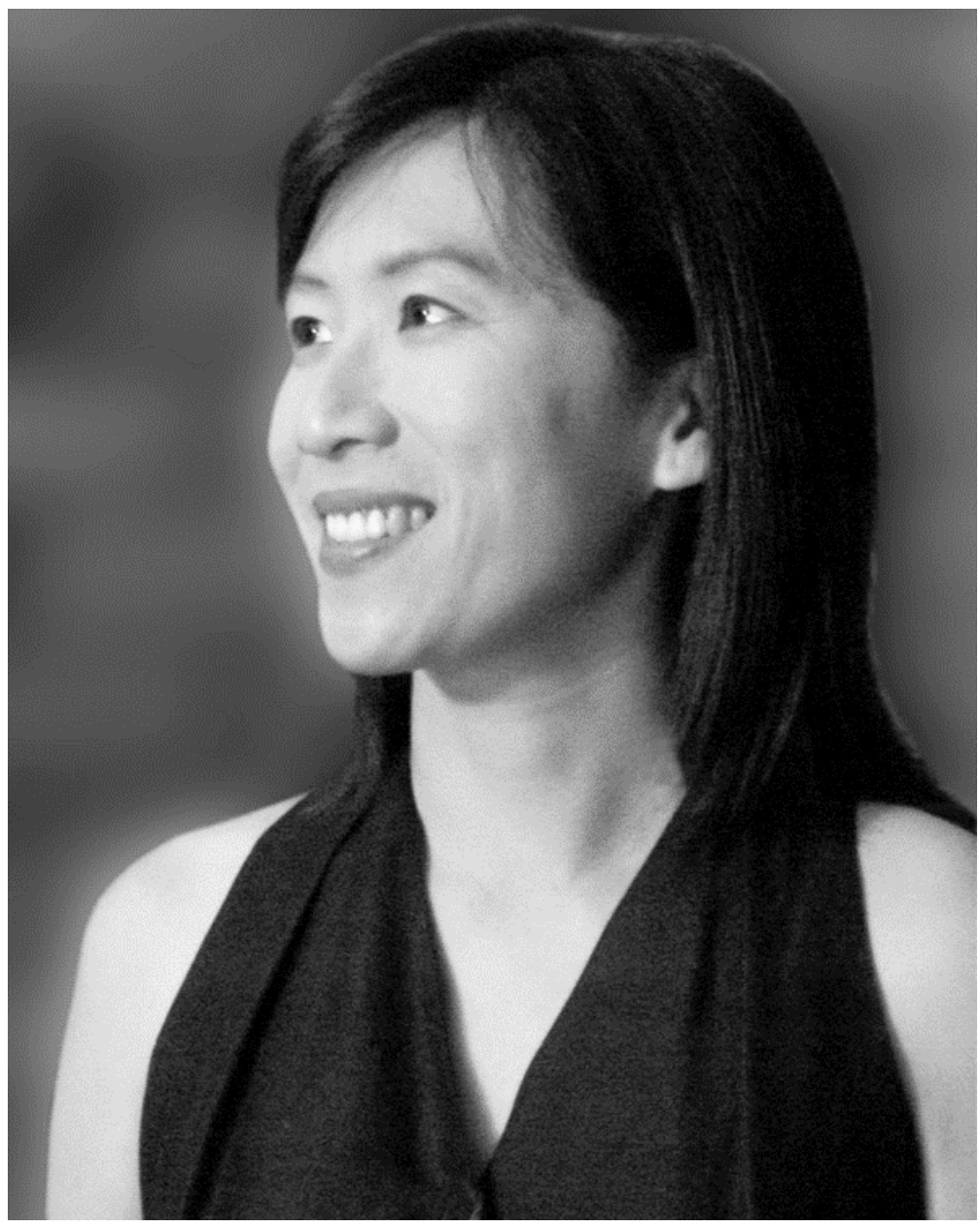

Figure 4.4 Photograph of Li-shan Hung ${ }^{129}$

As a winner of the Artists International, Li-shan Hung made her New York recital debut at Carnegie Hall's Weill Recital Hall in 2003 to great acclaim, which led to a return in 2005. Her performance of Cesar Franck's Prelude, Chorale, and Fugue was cited as "perhaps the finest performance of this piece I've ever heard" by Timothy Gilligan in the New York Concert

129 Photograph provided by Li-shan Hung, email to author, January 1, 2021. 
Review. She has also received high praises from reviews by the Washington Post and Baltimore Sun.

An active soloist and a chamber musician, Li-shan Hung has appeared internationally in such venues as Salle Gaveau in Paris, Cultural Center in Munich, Rachmaninoff Hall in Moscow, Shriver Hall Concert Series in Baltimore, Orpheus Classical Music Series in Chicago, Steinway Society of the Bay Area Recital Series in San Jose, Sejong Cultural Arts Center in Seoul, and National Concert Hall in Taiwan. Lishan has made guest appearances with the Taipei Symphony Orchestra, Stockton Symphony, MasterWorks Festival Orchestra, Palo Alto Philharmonic, Sheboygan Symphony, and Hunan Symphony Orchestra in China. She has collaborated with many distinguished artists including Menahem Pressler, Roberto Cani, and Delta David Gier. Her performances have been broadcast on Television and Radio stations in Wisconsin, San Francisco, Seoul, and so on.

Hung has been invited as a guest artist and presented master classes at universities and festivals in the U.S. and Asia, including Vanderbilt University, Ball State University, University of Northern Florida, Chinese University of Hong Kong, National Taiwan Normal University, and Xinghai Conservatory in China. During the summer she teaches at MasterWorks Festival in South Carolina and Cremona International Music Academy in Italy.

A native Taiwanese, Hung obtained her Doctor of Musical Arts and Master of Music degrees from Peabody Conservatory of the Johns Hopkins University, where she studied with the renowned pianist Ann Schein. In addition, she worked with Jorg Demus, Grant Johannessen, and the Alban Berg String Quartet, and performed in master classes with Abbey Simon, Paul Baduraskoda, Sergei Dorensky, and Evgeny Malinin. 
Dr. Hung now serves as Professor of Piano and the Keyboard Area Coordinator at Biola University. ${ }^{130}$

\section{When and where did you study with Ann Schein?}

I studied with Ms. Schein at the Peabody Institute of The Johns Hopkins University from 1991-1998.

\section{What repertoire did you study with Ann Schein?}

She helped to build my repertoire, including major works such as:

Mozart: Sonata in A Minor, K. 310; Concerto in C Minor, K. 491

Beethoven: Sonata in A Major, Op. 101; Sonata in A-flat Major, Op. 110;

Concerto No. 4 in G Major, Op. 58; Concerto No. 5 in E-flat Major, Op. 73

Schubert: Sonata in G Major, D. 894

Schumann: Davidsbündlertänze, Op. 6

Chopin: Concerto No. 1 in E Minor, Op. 11; Sonata No. 3 in B Minor, Op. 58;

Ballade No. 4 in F Minor, Op. 52; Polonaise-Fantaisie, Op. 61

Liszt: Piano Sonata in B Minor; Legend No. 2

Brahms: Fantasias, Op. 116

Mussorgsky: Pictures at an Exhibition

Bach/Busoni: Chaconne

Franck: Prelude Chorale, and Fugue

${ }^{130}$ Biography provided by Li-shan Hung, email to author, January 1, 2021. 
Debussy: Preludes

Prokofiev: Sonata No. 4 in C Minor, Op. 29; Piano Concerto No. 1 in D-flat Major, Op. 10

Scriabin: Piano Sonata No. 4 in F-sharp Major, Op. 30

Schoenberg: Sechs kleine Klavierstücke, Op. 19

Stravinsky: Piano Sonata

Bartók: Piano Concerto No. 3

Perle: Ballade

And lots of chamber repertoire, such as:

Schubert: Piano Trio No. 2 in E-Flat Major, Op. 100

Copland: Violin Sonata

Franck: Violin Sonata in A Major

Brahms: 3 Violin Sonatas; Piano Trio No. 1 in B Major, Op. 8

To this day, I still go back to study with her for pieces such as the Schumann Piano Concerto and Brahms Piano Concerto No. 2.

\section{What do you consider the most important things you learned from Ann Schein that you use} in your playing and/or teaching today?

a. "Love every note!" One needs not only to perfect the sound, phrasing, and shaping of a note, but also to find the true meaning behind it.

b. Don't impose your ideas on students but inspire them instead. She seems to always have a different key to unlock each and every student's problems! 
c. Each lesson is another level up. There is an unending amount of improvements that can be made.

d. Always have humility before composers and their compositions. Always have gratitude for every opportunity to make music. Always have respect for each student.

e. She is so caring. She was literally our piano mom. After lessons (she used to teach until 10 or $11 \mathrm{pm}$ ) we would stand at the garage entrance to chat for another hour, about our life, our challenges, our thinking, even our dreams!

f. Loving relationship with students and among students. She fostered a supportive atmosphere in the studio. Many still keep contact with each other, helping with one another's career. I use it as a model to shape my studio.

\section{How would you describe the approach to piano technique that Ann Schein taught?}

a. The technique ultimately must serve the music.

b. She gave innovative/magic fingerings, such as in Davidsbündlertänze, Chopin B Minor Sonata, Schumann Piano Concerto, Brahms Piano Concerto No. 2, Franck Sonata, etc.

\section{How would you describe the approach to interpretation that Ann Schein taught?}

a. Constantly asking questions to stimulate and guide my thinking.

b. Insightful analysis, especially in the harmonic aspect.

c. "Sing and shape the phrase" is a crucial element.

d. Study about the composers, compositional background, study the scores, etc. 
e. I love her analogies/descriptions, which enlightens me instantly. For instance, "Ballet. Choreograph it!" for the middle part in the second movement of the Stravinsky Piano Sonata; "Liebeslieder Waltz" for the middle section of Brahms Op. 116, No. 7.

f. Vast knowledge of the chamber music repertoire certainly plays a big role in her interpretation as well, as her husband Earl Carlyss is a former second violinist with the Juilliard String Quartet. For instance, she often mentioned the sound of the String Quartet for Beethoven Sonatas. As another example, when I was working on Stravinsky Piano Sonata, she asked me to listen to his Duo for Violin and Piano.

\section{Did Ann Schein teach you any practice skills or daily routines to follow?}

a. To practice hard passages: rhythms, different articulations, shifting accents, etc,

b. To prepare for performances: multiple run-throughs, e.g. for Chopin Concerto, No. 1, run through 3 times in a row.

\section{Is there anything else you would like to add about your studies with Ann Schein?}

She trained me to be a more complete musician.

I feel tremendously privileged to have studied with Ann Schein. She helped shape me to become who I am today as a pianist, teacher, and a person. She is a treasure for the world! ${ }^{131}$

${ }^{131}$ Li-shan Hung, email to author, December 31, 2020. 


\section{Mansoon Han Kim}

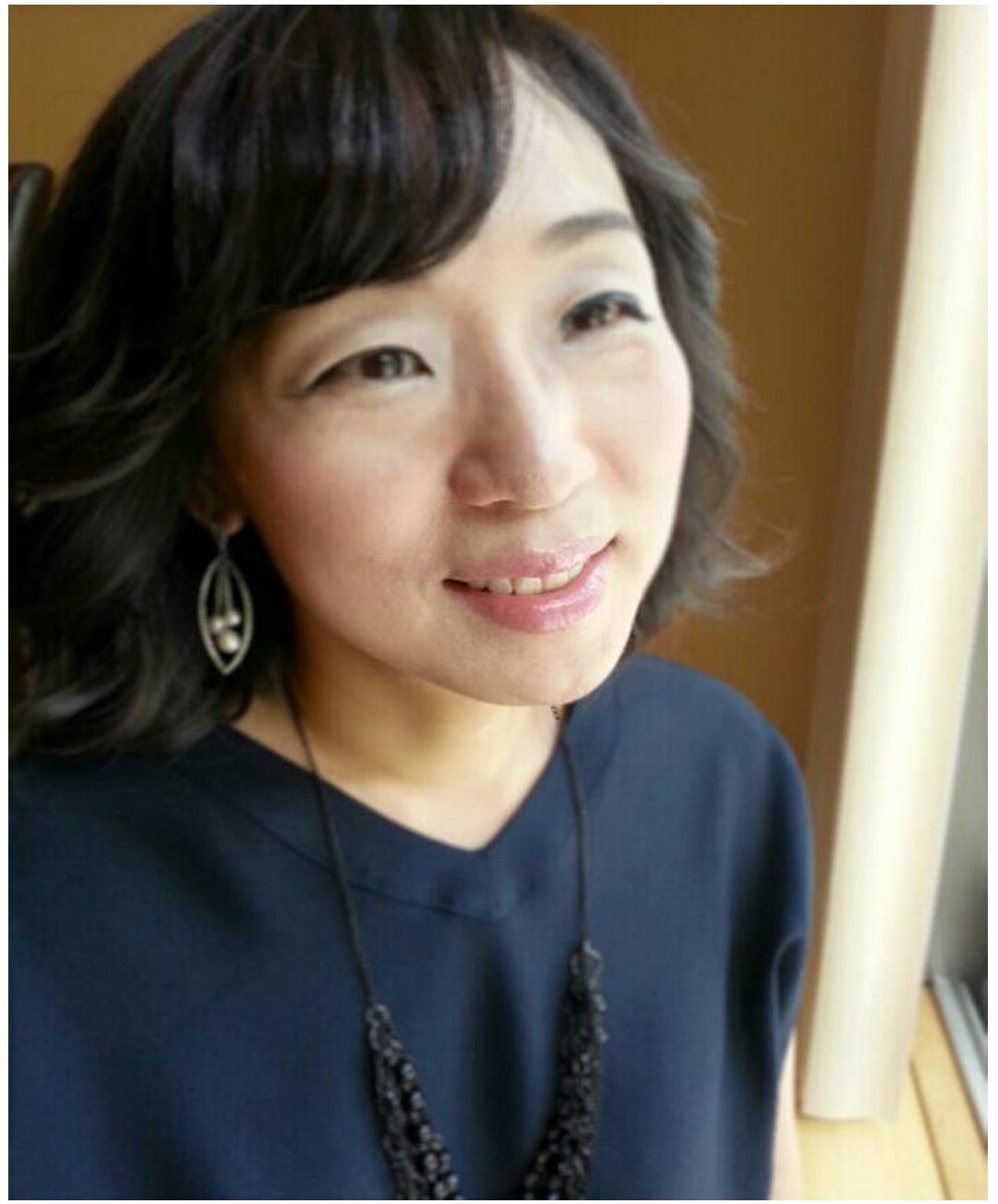

Figure 4.5 Photograph of Mansoon Han $\mathrm{Kim}^{132}$

Dr. Mansoon Han Kim has won numerous competitions including the Yale Gordon Competition, the Yook Young Competition, the Piano Music Competition, and Nan Pa Music Competition. She received her Bachelor of Music degree from Seoul National University with Honor. After coming to the United States, she began studies with concert pianist Ann Schein at

132 Photograph provided by Mansoon Han Kim, email to author, January 3, 2021. 
the Peabody Institute in Baltimore, Maryland, where she received her Master of Music and Doctor of Musical Arts degrees.

She has performed throughout the United States, Canada, South Korea, and China. She has performed with members of the Maia String Quartet, Ceruti String Quartet, the Anchor Trio, and soprano Hyunah Yu. Kim has won the Clara Ascherfeld Accompanying Award, Peabody Career Development Grant. She has studied at summer festivals such as the Aspen Music Festival, the Orford Arts Centre, and the Kent Blossom Summer Chamber Music Festival and participated in master classes by Menahem Pressler, Leon Fleisher, Abbey Simon, Jörg Demus, Sergei Dorensky, and Gabby Casadesus.

As an educator, she gave master classes at Arizona State University, Southern Illinois University, and the Pianofest held at Nyack College. After serving as an Assistant Professor at Hope College in Holland, Michigan, she is currently an Adjunct Professor at the Cali School of Music, Montclair State University where she works as a coordinator of the Secondary Piano area. $^{133}$

\section{When and where did you study with Ann Schein?}

I studied with Ann Schein at Peabody Conservatory from 1992 to 2000. I did my MM, GPA and DMA there. I had a friend named Michung Park who was studying with her at that time before me. She talked about her teaching style, who she was and what kind of person she was, which grew an interest in me wanting to take a few lessons from her. I was living in Korea at that time. I took a flight all the way from Korea to meet her and took some lessons from her during

${ }^{133}$ Biography provided by Mansoon Han Kim, email to author, January 3, 2021. 
the winter break. During my stay in the States, I had a chance to hear her perform the Rachmaninoff Piano Concerto, No. 3 in NYC. When I heard her play, I decided to come to the US only to study with her. She was playing exactly the way I longed for!

\section{What repertoire did you study with Ann Schein?}

Bach: Partita No. 2 in C Minor, BWV 826

Beethoven: Piano Sonata in A Major, Op. 101; Piano Sonata in A-flat Major, Op. 110

Haydn: Piano Sonata in C Major, Hob.XVI:50

Schumann: Piano Sonata in F-sharp Minor, Op. 11

Liszt: Piano Sonata in B Minor

Brahms: Piano Sonata in C Major, Op. 1; Piano Concerto in D Minor, Op. 15

Chopin; Sonata in B-flat Minor, op. 35

Ravel: Jeux d'eau, Miroirs

Franck: Symphonic Variations

\section{What do you consider the most important things you learned from Ann Schein that you use in your playing and/or teaching today?}

First, freedom in playing. I used to be caught up with being able to play every note without any mistake with good dynamic, tempo and structural analysis. I felt something lacking in my mind about my playing; it was almost like you are yearning for something you don't know but it is there somewhere. Until I met Ann Schein, performance for me was like carrying a very fragile piece of china on ice without an accident. I was shocked how she sincerely found things that she 
liked about my playing. It was quite different since I came from receiving a list of things to fix for the next lesson. My goal for the next lesson was to fix all the errors that I made to improve. However, after hearing me play, she would always start a lesson by giving me heartfelt compliments about my playing and why she loved them. Her sincere compliments truly encouraged me to explore more freely what I wanted to express. She gave me a courage that it was okay to bring out what I felt inside. She was a true genius in sensing potential and the inner self within me. Second, originality. She asked me so many questions in lessons. Instead of giving specific instructions, she wanted me to find them on my own. She always said she never wanted anyone to imitate her. Therefore, even with the same piece, she would give different lessons from person to person. It was quite interesting to see how one can play so differently from another in our rep classes! Third, the meaning of music. She would ask a question after a question quite often during lessons. She would ask me why I was doing certain things. She taught me even if the playing was beautiful and nice, it was not a convincing playing if you didn't understand the meaning of a piece that you were playing and what for.

\section{How would you describe the approach to piano technique that Ann Schein taught?}

I came from a background of mainly relying on finger controls and rotation of the wrist and arm. She taught me how to use the arm and body weight. That was a game changer for me since I was finally able to achieve a deep and grand sound in my playing without an effort, which I always wanted! 


\section{How would you describe the approach to interpretation that Ann Schein taught?}

First, she had an in-depth knowledge about composers. She put an emphasis of understanding of the composer that you were working on. Second, three basic ingredients of music: harmony, rhythm, melody. She always asked me what key I was in since the key determined the moods. She was a fundamentalist for the rhythm. She would never accept any bended rhythm for any reason. She believed the true beauty in simplicity. The melody cannot be conveyed without phrasings. She would always sing the melody, which was more than enough for me to understand the phrasings. She believed in a natural singing line. Her phrasings were always natural. Second, I learned a lot about colors. She hated monotonous playing. She challenged me to try to come up with varying colors all the time. She said, colors can be created by varying the weight of the arm and/or finger weight as well as by contact points of your fingers, tip or flat part of your fingers.

\section{Did Ann Schein teach you any practice skills or daily routines to follow?}

Rhythms! There would be no one who knows what that means unless you studied with her.

\section{Is there anything else you would like to add about your studies with Ann Schein?}

Not only was she one of the greatest teachers and pianists, but also was she a wonderful person. She was a great role model for me for how to be a good teacher and a person. She would go extra miles for anyone who needed her help. We would have dress rehearsals and chamber music rehearsals at midnight if it was the only time available. She was always happy to be there 
and helped her students, which came from her sincere love for music and her students. She was the first teacher who truly taught me to love music at a deeper level of understanding. ${ }^{134}$

134 Mansoon Han Kim, email to author, January 3, 2021. 


\section{Mark Markham}

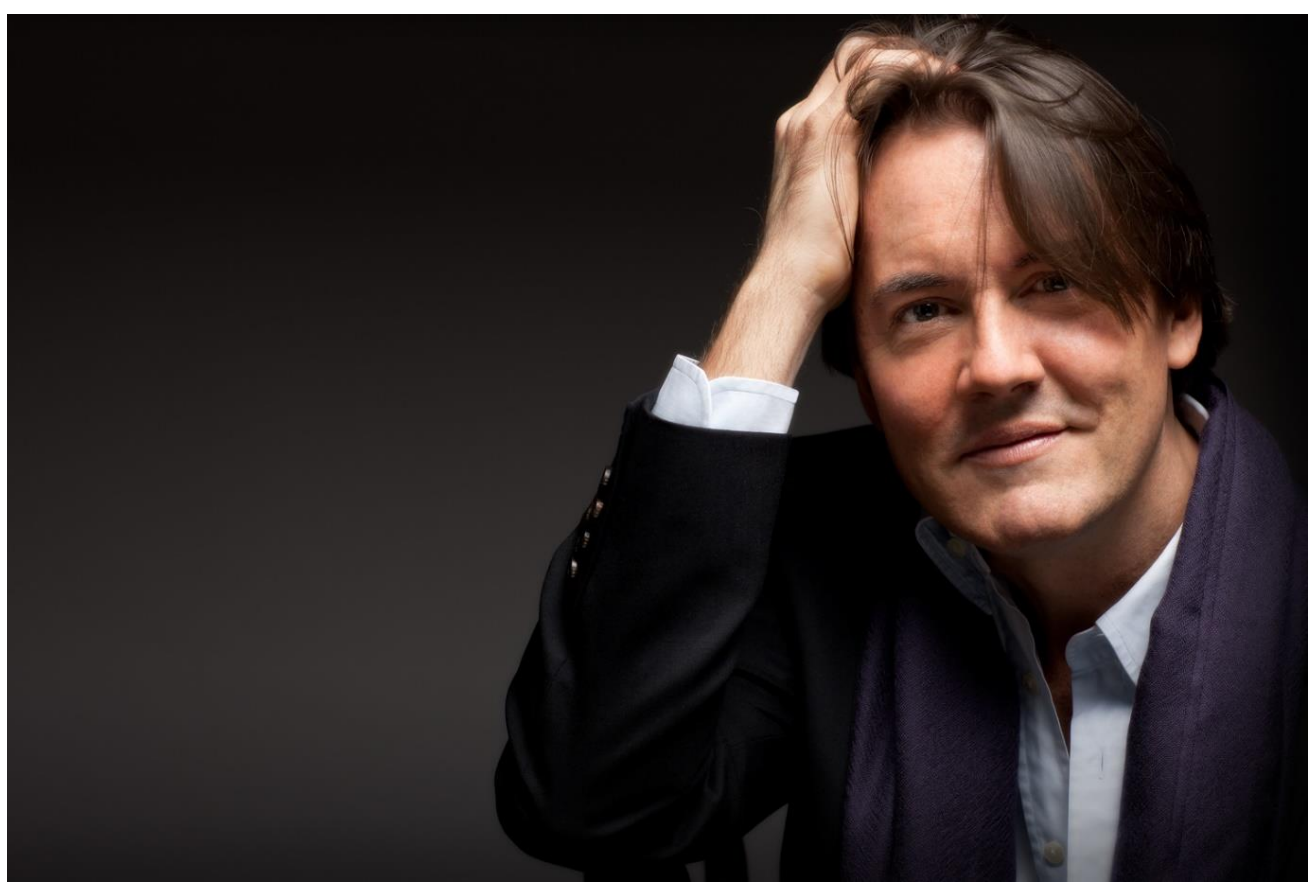

Figure 4.6 Photograph of Mark Markham ${ }^{135}$

Born in Pensacola, Florida, Mr. Markham made his debut in 1980 as soloist with the New Orleans Symphony Orchestra and in the same year was invited by the renowned Boris Goldovsky to coach opera at the Oglebay Institute. His teachers at the time, Robert and Trudie Sherwood, were supportive of all his musical endeavors from solo repertoire, vocal accompanying, and chamber music to Broadway and jazz. During the next ten years as a student at the Peabody Conservatory, where he received the BM, MM and DMA degrees in piano performance, this same support for the diversity of his musical gifts came from Ann Schein, a pupil of Mieczysław Munz and the great Artur Rubinstein. While under her tutelage he won several competitions including the Munz Competition and the First Prize and the Contemporary Luc Fievet.

135 Photograph provided by Mark Markham, email to author, January 4, 2021. Photo credit Jean- 
Music Prize at the 1988 Frinna Awerbuch International Piano Competition in New York City. While still a student at the conservatory Mr. Markham toured with soprano Phyllis Bryn-Julson, a collaboration that resulted in critically acclaimed recordings of works by Messiaen, Carter, Dallapiccola, Schuller, and Wuorinen. In addition, he has toured the US, Europe, and Asia with countertenor Derek Lee Ragin and has given recitals with Gordon Hawkins, Theodora Hanslowe, Christine Brewer, Isabel Leonard and Vinson Cole.

Starting in 1995 for twenty seasons, Mr. Markham was the recital partner of Jessye Norman, giving nearly 300 performances in thirty countries, including recitals in Carnegie Hall, the Concertgebouw in Amsterdam, the Philharmonie in Berlin, La Palau de la Musica in Barcelona, London's Royal Festival Hall, the Musikverein in Vienna, the Salzburg Festival, Bunka Kaikan in Tokyo, Mann Auditorium in Tel Aviv, the Ancient Theatre of Epidaurus in Greece, the Baalbek Festival at the Temple of Bacchus in Lebanon, and at the 2002 Nobel Peace Prize presentation to President Jimmy Carter in Oslo.

Much appreciated by the public for his improvisational skills, Mr. Markham performed at the Expo 2000 in Hannover, Germany, where he collaborated with Sir Peter Ustinov for a live television broadcast throughout the country. His gift for jazz has been recognized in the Sacred Ellington, a program created by Ms. Norman in which he served as pianist and musical director, which toured Europe, the Middle East and finished in 2009 with a performance at the Cathedral of St John the Divine in New York City. His recording with Jessye Norman of "Roots: My Life, My Song" was nominated for a Grammy Award.

Mr. Markham is a former faculty member of the Peabody Institute of The Johns Hopkins University, Morgan State University, the Norfolk Festival of Yale University and the Britten- 
Pears School of the Aldeburgh Festival in England. He has given master classes throughout the US, Europe and Asia and has been a guest lecturer for The Johns Hopkins University and the Metropolitan Opera Guild. ${ }^{136}$

\section{When and where did you study with Ann Schein?}

I studied with Ann Schein at the Peabody Conservatory in Baltimore from the fall of 1982 to spring of 1991.

\section{What repertoire did you study with Ann Schein?}

Bach: Prelude and Fugue in E-flat Major

Mozart: Sonata in B-flat Major, K. 570; Concerto in E-flat Major, K 271; Piano Trio in E Major, K. 542

Clementi: Sonata in B-flat Major, Op 24, No 2

Haydn: Sonata in E-flat Major, Hob XVI:49 and Hob XVI:52

Beethoven: Sonata in A-flat Major, Op. 26; Sonata in A Major, Op. 101

Schubert: Impromptu in G-flat Major, Op. 90, No. 3

Chopin: Preludes, Op. 28; Ballade in G Minor, Op. 23; Sonata No. 2 in B-flat Minor, Op. 35; Études, Op. 10

Brahms: Sonata No. 3 in F Minor, Op. 5; Fantasies, Op. 116

Schumann: Fantasiestücke, Op. 12

Liszt: Sonata in B Minor, Paganini Études, "Harmonies du soir"

136 Biography provided by Mark Markham, email to author, January 4, 2021. 
Scriabin: Étude in C-sharp Minor, Op. 2, No. 1; Étude in D-sharp Minor, Op. 8, No. 12;

Preludes, Op. 16

Debussy: Étude pour les sonorités opposes, Étude pour les octaves, Des pas sur la neige, Les collines d'Anacapri

Ravel: Gaspard de la nuit, Piano Trio

Prokofiev: Concerto No. 3 in C Major, Op. 26

Rachmaninoff: Étude-tableaux in D Major, Op. 39, No. 9; Hopak (Mussorgsky)

Bartók: Sonata for Piano, Concerto No. 2

Bernstein: Touches

Barber: Sonata for Piano

Schoenberg: Drei Klavierstücke, Op. 11

\section{What do you consider the most important things you learned from Ann Schein that you use in your playing and/or teaching today?}

Probably the most important thing I learned from Ann Schein is that everything that you want to say is in the sound you make and that this sound comes from your imagination and your relationship with the instrument. The possibilities of sound are endless and she encouraged this. A composer's intentions come before my own. It is important to know about the life of a composer - when they lived, what was going on historically, what was their life like, what was their own sound like, if it was possible to know this. Who were their teachers. For which pianists did they write music. A huge part of studying with Ann was fingering. There were times when she would take my score home with her and put in the fingering she wanted me to use. For 
example: the last movement of the Chopin Sonata No. 2. While all hands are different, there were certain pieces where she imposed her fingering and it made complete sense. The fingering had to produce the sound that you wanted and finding that fingering is actually as important as having a sound in your head.

\section{How would you describe the approach to piano technique that Ann Schein taught?}

I remember vividly the first time I asked her about technique. Her verbal response was that it should be natural and then she demonstrated and added that it was one note after the other. The simpler the better. There was no secret formula, except to practice well. There was no "hitting or banging" on the piano. Your sound was a result of your thoughtfulness for the music. (More detail in question \#6)

\section{How would you describe the approach to interpretation that Ann Schein taught?}

Style is a very special word, but a very important one in music. Ann's approach was that the expression of a work of music should be organic. There are no special effects. It is about the simplest and most direct path to the heart of the music. If you didn't believe in an idea, then don't do it, just because you heard Horowitz do it. We talked a lot about the harmonic language of each composer and searched for what was their language of expression. One's emotional response to a harmony should produce a corresponding color. It is one thing to have ideas, but they must be grounded in the musical storytelling. Poetry above all. 


\section{Did Ann Schein teach you any practice skills or daily routines to follow?}

Ann passed on practice exercises that she had learned with her teacher Munz. There were many rhythmic exercises, especially for passage work and in all études. When I studied the Chopin Études, Op. 10 with her, I began with no 1. If one did the work she requested, you would work through the piece 16 times at one sitting. The piece is all 16th notes. The first time through, one stops on the first note of each group of 4 . You play the piece through 4 times this way. Then, stopping on the 2 nd note of each group (4 times through), then the $3 \mathrm{rd}$, etc. It would take an hour each day to do this, but the piece was memorized after a week. That summer in Aspen she had me perform it in a master class after only two weeks of work. I survived and the piece is still in my hands 36 years later. Repetition is a great way to learn music, but one must practice musically!

\section{Is there anything else you would like to add about your studies with Ann Schein?}

Ann has an uncanny ability to sense what each student needs. Her students all sound like themselves. There are no carbon copies of her. She is a huge musical and pianistic personality, but never does she try to get another pianist to play or to sound like she does. Her innate desire to free the spirit of each individual is a quality that one rarely finds in a teacher. While some teachers might talk first about what did not work after a performance, Ann would always focus on what was exceptional. I remember those conversations to this day and am eternally grateful that she shared those thoughts with me, because now I understand that those moments were when 
I was in complete service to the music. She taught me to be a champion of music. There is nothing better. ${ }^{137}$

137 Mark Markham, email to author, January 4, 2021. 


\section{CHAPTER V}

\section{CONCLUSION}

Mieczysław Munz's prediction of "a long life in music"138 for his young student turned out to be prophetic. Since her marathon debut in 1957, Ann Schein's career has taken her around the world bringing music to more than fifty countries. She has performed the concertos of Mozart, Beethoven, Chopin, Schumann, Brahms, Tchaikovsky, Rachmaninoff and others with the world's leading orchestras and given recitals in the world's major concert venues. She has “extended the legacy of her teachers Mieczysław Munz, Arthur Rubinstein and Dame Myra Hess"139 with such events as her historic 1980-1981 New York Chopin recital series and established a lasting testament to the disciplined work that Munz taught her through such feats as surpassing one hundred performances of Rachmaninoff's Piano Concerto No. 3 in D Minor, Op. 30. In addition to the music of the standard repertoire, Schein has been a champion of contemporary music, a trait instilled by her earliest teachers, Dr. and Mrs. Gunn. Schein has also performed around the world as a cultural ambassador for the United States State Department and participated in several important collaborations including with her life-long friend soprano Jessye Norman and her husband violinist Earl Carlyss. Finally, her many recordings immortalize her performances making them available for a wide audience now and into the future.

Both Schein's live performances as well as recordings have received ecstatic reviews from her earliest recitals as a child. Critics have praised not only the virtuosity of her performances,

138 Schein, "Biography."

139 Ibid. 
but also the subtleties and artistic depth of her interpretations. Perhaps the Washington Post critic summarized it best in his oft-quoted remarks: "Thank Heaven for Ann Schein...what a relief it is to hear a pianist who, with no muss or fuss, simply reaches right into the heart of whatever she is playing - and creates music so powerful you cannot tear yourself away." ${ }^{140}$ Indeed these are qualities imparted to Schein by all her teachers and qualities that she stresses to students particularly in the current technological age with its rapid pace and audience's attraction to flashy performances that may be devoid of deep musical meaning.

Schein's longevity in music has given her a myriad of experiences to draw from in giving advice to students and speaking to the necessary qualities for successful musicians. Particularly she advises students to establish a daily practice routine, to read extensively about the composers, to listen to recordings of the great musicians of the $20^{\text {th }}$ century, to get physical exercise and to play chamber music. She also advises students to be wary of using competitions as a way to succeed in music. In addition to the above advice, Schein considers "good health, an optimistic spirit, a curiosity for music and life in general, a good feeling for communicating music to the audience in a fresh and spontaneous way, and the courage to face adversity, failure and life's shocks with courage and hope" as essential traits for musicians. She also emphasizes the necessity for a "Team of Support" in a musical career.

As a teacher, Schein has passed on the legacy of her teachers to hundreds of students from numerous nationalities over several decades. She has held positions at the Peabody Institute of The Johns Hopkins University, the Aspen Music Festival and School, Indiana University, the Eastman School of Music, Stony Brook University and the Mannes School of Music as well as

140 Ibid. 
given countless masterclasses and residences throughout the world. Schein describes teaching as "People Work" and enjoys the new musical revelations that teachers gain from looking at familiar repertoire with each new student.

In addition to her own accomplishments, Schein's legacy as a teacher can be seen in the successful careers of her students, including the six interviewed in this paper. Their achievements include positions at prominent universities, recordings, publications and worldwide performing careers as soloists, chamber musicians, period specialists, and accompanists/coaches. From their interview responses, one quickly gets a sense of the highly personal and individualized nature of Schein's teaching. Specifically Markham mentions her "uncanny ability to sense what each student needs." Although it is impossible to summarize all responses, several generalizations can be gleaned about Schein's teaching especially as it relates to technique, practice routines and interpretation.

As Bengtson indicates, Schein's approach to technique "was never dogmatic but had a wide variety of approaches for particular circumstances." Hung provides a guiding principle for Schein's technical advice, however, when she mentions Schein's advice that "the technique ultimately must serve the music." One of the most frequent responses to this question was Schein's emphasis and expertise on good fingering, a trait she undoubtedly inherited from Munz. Another prevailing tenet was what Bengtson describes as "a full body approach." This idea is furthered by Kim who mentions Schein's use of "arm and body weight" versus "relying on finger controls and rotation of the wrist and arm" to achieve "a deep and grand sound." Markham concludes that Schein's advice was that technique "should be natural.... one note after the other. The simpler the better." 
For practice routines, the most frequently given answer was practicing in rhythms for difficult passagework. This could take many forms, but Markham provides a detailed description of a rhythmic exercise that allowed him to learn Chopin's difficult Étude in C Major, Op. 10, No. 1 in two weeks' time and keep it in his repertoire for 36 years. Such a feat is a testament to the well-disciplined practice approach that Schein advocates. Other practice routines mentioned include "a doubling-up practice method [where] pattern $\mathrm{ABC}$ becomes AABBCC" (Bengtson), "creating your own exercises to solve technical problems" (Chang) and "multiple run-throughs to prepare for performances" (Hung).

For interpretation, the prevailing idea one receives is that Schein's teaching was never "spoon-fed," but consisted of "constantly asking questions to stimulate and guide my thinking" (Hung). Kim relates that Schein "said she never wanted anyone to imitate her," the same advice that Rubinstein once passed on to her. There is also the belief that Schein gave one confidence in his/her own sound and interpretation or, as Faliks phrased it, Schein "possesses a rare ability to recognize personality, individuality in a student, and treasure it and help develop it.” Other features of Schein's interpretation advice that are highlighted include going beyond solo piano music to other works of a composer for ideas of sound as well as the need to have a thorough knowledge about the composer to inform one's interpretation.

In addition to being a renowned performer and teacher, Schein's students paint a portrait of her caring and generous spirit that "profoundly touched everyone who had a privilege to work with her" (Chang). Faliks describes that "[Schein] was like a mom to me when I was at Peabody." There are also several anecdotes describing late-night lessons, conversations, and dress rehearsals that demonstrate Schein's unlimited giving to her students. Furthermore, Schein 
is a woman of faith who has relied on God and prayer to "[sustain her] through every circumstance." A wife, mother and grandmother as well, Schein seems to have found the way to balance both a successful career and personal life.

In conclusion, Schein's historic career places her among the most significant pianists of the past century. Her studies with Dr. and Mrs. Gunn, Munz, Rubinstein and Hess propelled her to an international performing career spanning more than six decades. As a teacher, she has passed on the knowledge gained from them and her own experiences to countless numbers of students. The record of this knowledge provided here and in other sources forms a lasting pedagogical tribute to Schein. As Porter remarks, "Schein continues to make a significant mark on American music history." ${ }^{" 141}$ Schein remains active both performing and teaching. Thus her legacy will continue to grow both through her own contributions and the contributions of her students as they pass on the knowledge that she faithfully imparted to them.

141 Porter, 192. 


\section{APPENDIX A}

\section{TIMELINE OF EVENTS IN THE LIFE OF ANN SCHEIN}

1939 Born in White Plains, New York on November 10

$1942 \quad$ Adopted by Ernest and Betty Schein

1945-1953 Studied with Dr. Glenn Dillard and Mrs. Bessie Bracken (B.B.) Gunn in Washington D.C.

$1946 \quad$ First solo recital at the YWCA’s Barker Hall

1950 Concerto debut with the Washington Civic Symphony Orchestra performing the first movement of Beethoven's Piano Concerto No. 1 in C Major, Op. 15

1953 Youngest winner of the Interlochen National Music Camp's Concerto Competition with the first movement of MacDowell's Piano Concerto No. 2 in D Minor, Op. 23

1953-1958 Studied as a special student of Mieczysław Munz at the Peabody Institute

1954-1955 Spent the summer months in Mexico City with Munz having six-to-eight-hour lessons daily

1956 First of over 100 hundred performances of Rachmaninoff's Piano Concerto No. 3 in D Minor, Op. 30 at Peabody Conservatory

1957 Debut in Mexico City with a three-week program including Rachmaninoff's Piano Concerto No. 3 in D Minor, Op. 30, Tchaikovsky's Piano Concerto No. 1 in B-flat Minor, Op. 23 and a solo recital

1958 First European tour of 12 countries including England, Iceland, Norway, Sweden, Denmark, Poland, Germany, Switzerland and Greece

1961 First recordings for Kapp records included recording Rachmaninoff's Piano Concerto No. 3 in D Minor, Op. 30 and Chopin's Piano Concerto No. 2 in F Minor, Op. 21 in the same week

1961-1962 Studied with Arthur Rubinstein in Paris and Lucerne, Switzerland as well as with Dame Myra Hess in England 
First tour of the Soviet Union

1962 Carnegie Hall debut on March 28

1962 Added to the roster of Russian impresario Sol Hurok

1963 Performed at the White House on April 17

1963 First appearance at the BBC Proms with the London Symphony Orchestra performing Rachmaninoff's Piano Concerto No. 3 in D Minor, Op. 30

1964-1975 Performed in over fifty countries as part of a cultural exchange on behalf of the U.S. State Department

1966 Second tour of the Soviet Union

$1967 \quad$ Father died of cancer in June

1967 Mother died of heart failure in December

1969 Married Earl Carlyss in White Plains, New York on May 24

$1971 \quad$ Birth of daughter Linnea

$1973 \quad$ Birth of daughter Pauline

1980-1981 Performed a six-recital series of the major works of Chopin at Alice Tully Hall in New York

1980-2001 Faculty of the Peabody Institute

1982-1987 Performed with the American Chamber Players including several recordings

1984-2016 Artist Faculty at the Aspen Music Festival and School: appeared in over 90 performances of solo, chamber works and concerti: Victoria and Ronald Simms Chair (2006-2008)

1992-1995 Performed with soprano Jessye Norman including a recording of Berg Lieder

2008-2009 Visiting Faculty member at Indiana University

2012 Received Distinguished Alumni Award from the Peabody Institute 
2015 Recital and presentation at the MTNA National Conference in Las Vegas:

honored for more than 50 years as a Steinway artist

2015-2016 Visiting Professor at the Eastman School of Music

2016- Part-time faculty at the Mannes School of Music

2018 Received Lifetime Achievement in the Performing Arts by the National Museum of Women in the Arts in Washington D.C.

2019 Performance of Chopin's Piano Concerto No. 2 in F Minor, Op. 21 with the Peabody Symphony Orchestra in celebration of her $80^{\text {th }}$ birthday

2020 Carnegie Hall recital on March 11 in commemoration of the $40^{\text {th }}$ anniversary of her 1980-1981 Chopin recital series 


\section{APPENDIX B \\ PROGRAMS OF ANN SCHEIN'S 1980-1981 NEW YORK CHOPIN RECITAL SERIES}

Schein's six-recital Chopin series performed at Alice Tully Hall in New York from October 1980 - March 1981 was the first Chopin series performed in New York since the 1940s and also a turning point in Schein's career. Included here are the dates and programs for each recital as well as a personal anecdote from Schein.

\section{Recital \#1}

Monday, October 13, 1980

Program: Piano Sonata No. 1 in C Minor, Op. 4

Piano Sonata No. 2 in B-flat Minor, Op. 35

Intermission

Piano Sonata No. 3 in B Minor, Op. 58

\section{Recital \#2}

Monday, November 3, 1980

Guest Performers: Kristine Ciesinski, soprano

Program: Polonaise in B-flat Minor, Op. posth. (1826)

Polonaise in A Major, Op. 40, No. 1

Polonaise-Fantaisie, Op. 61 


\section{Eight Songs}

(“The Maiden's Wish," “The Promised Land," “The Warrior," "Death's

Division," "My Sweetheart," “The Betrothed," "Lithuanian Song," "Leaves are

\section{Falling")}

Intermission

Ballade No. 1 in G Minor, Op. 23

Ballade No. 2 in F Major, Op. 38

Ballade No. 3 in A-flat Major, Op. 47

Ballade No. 4 in F Minor, Op. 52

\section{Recital \#3}

Monday, December 1, 1980

Guest Performers: The Jupiter Symphony, Jens Nygaard, conductor

Program: Fantaisie on Polish Airs, Op. 13

Piano Concerto No. 2 in F Minor, Op. 21

Intermission

Variations on “Là ci darem la mano," Op. 2

\section{Recital \#4}

Monday, January 19, 1981

Program: Mazurka in B Major, Op. 56, No. 1 
Mazurka in A-flat Major, Op. 59, No. 2

Mazurka in F Minor, Op. 63, No. 2

Impromptu No. 1 in A-flat Major, Op. 29

Impromptu No. 2 in F-sharp Major, Op. 36

Scherzo No. 2 in B-flat Minor, Op. 31

Scherzo No. 1 in B Minor, Op. 20

Intermission

Scherzo No. 4 in E Major, Op. 54

Fantaisie-Impromptu in C-sharp Minor, Op. post. 66 (autograph version)

Impromptu No. 3 in G-flat Major, Op. 51

Scherzo No. 3 in C-sharp Minor, Op. 39

\section{Recital \#5}

Monday, March 16, 1981

Guest Performers: Earl Carlyss, violin

Joel Krosnick, cello

Charles Wadsworth, piano

Program: Twenty-Four Preludes, Op. 28

Intermission

Piano Trio in G Minor, Op. 8

Variations in D Major for Piano Duet

Grand Duo Concertante for Cello and Piano on Themes from Robert le Diable 


\section{Recital \#6}

Monday, March 30, 1981

Program: Nocturne in F Major, Op. 15, No. 1

Nocturne in C Minor, Op. 48, No. 1

Twelve Études, Op. 10

Intermission

Twelve Études, Op. 25

\section{Anecdote from Ann Schein}

I would love to share the story of The New York Times full page ad appearing in September, announcing the Series, which Arthur Rubinstein saw, and called to invite me to a cocktail party in his Waldorf-Astoria apartment. I was so scared that he would be angry at such a pretentious undertaking, and went, full of nervous anticipation. Not only did he answer the door, but he held out his arms to me and said, "Ann — this is WONDERFUL! That's the Way to Do It" Come in-we can talk about plans to bring a piano here in the next weeks, and we can go over the repertoire together"! And that is what happened for two unforgettable weeks. He had not heard the songs since his youth, and he cried as he heard them again. Munz had already passed away, and I suspect that when this project was proposed to me, he would not have allowed me to do it. I will never know! Preparing for it for two years, and accomplishing it, changed my life in so many treasured ways. ${ }^{142}$

142 Ann Schein, email to author, February 23, 2021. 


\section{APPENDIX C \\ DISCOGRAPHY OF ANN SCHEIN}

This discography documents recordings of Schein released within the United States including solo and collaborative works, concerti as well as compilation sets. Schein's early Kapp recordings were released on LPs and not rereleased on CD. Some of her collaborative recordings, however, were rereleased on CD. Repertoire is specified for recordings only when it is not provided in the citation or when needed to identify the pieces performed by Schein on collaborative and compilation recordings.

\section{Early Kapp Recordings}

Schein, Ann (piano). Miss Ann Schein: A Truly Brilliant Pianist. Kapp Records KCL - 9040, 1959, LP.

Repertoire:

Chopin: Scherzo No. 1 in B Minor, Op. 20

Chopin: Scherzo No. 2 in B-flat Minor, Op. 31

Chopin: Scherzo No. 3 in C-sharp Minor, Op. 39

Chopin: Scherzo No. 4 in E Major, Op. 54

Schein, Ann (piano). A Piano Invitation to the Dance. Kapp Records KC-9042-S, 1960, LP.

Repertoire:

Weber-Tausig: Invitation to the Dance, Op. 65

Medtner: "Danza Festiva,” Op. 38, No. 3

Halffter: Danza de la Pastora 


\section{Bartok: Romanian Folk Dances}

Bizet-Rachmaninoff: Minuet from L'Arlesienne

Chopin: Waltz in D-flat Major, Op. 64, No. 1 ("Minute Waltz")

Chopin: Mazurka in A-flat Major, Op. 59, No. 2

Chopin: Mazurka in F-sharp Minor, Op. 59, No. 3

Chopin: Polonaise-Fantaisie in A-flat Major, Op. 61

Schein, Ann (piano). Études. Kapp Records K-9023-S, 1960, LP.

Repertoire:

Debussy: Étude No.11, Pour les arpeges composes

Szymanowski: Étude in B-flat Minor, Op. 4, No. 3

Moszkowski: Étude in F Major, Op. 72, No. 6

Scriabin: Étude in B-flat Minor, Op. 8, No. 7

Scriabin: Étude in C-sharp Minor, Op. 2, No. 1

Rachmaninoff: Étude-Tableaux in E-flat Minor, Op. 33, No. 6

Liszt: "Gnomenreigen," S. 145, No. 2

Chopin: Étude in A-flat Major, Op. 25, No. 1

Chopin: Étude in F Minor, Op. 25, No. 2

Chopin: Étude in F Major, Op. 25, No. 3

Chopin: Étude in G-flat Minor, Op. 25, No. 9

Chopin: Étude in A-flat Major, Op. post.

Chopin: Étude in C-sharp Minor, Op. 10, No. 4

Chopin: Étude in A-flat Major, Op. 10, No. 10 
Chopin: Étude in C Major, Op. 10, No. 7

Chopin: Étude in F Major, Op. 10, No. 8

Chopin: Étude in C Minor, Op. 10, No. 12

Schein, Ann (piano). Piano Concerto No. 3 in D Minor, Op. 30, by Sergei Rachmaninoff with the Vienna State Opera Orchestra, conducted by Sir Eugene Goossens. Kapp Records KDC-6000-S, 1960, LP.

Schein, Ann (piano). Piano Concerto No. 2 in F Minor, Op. 21, Nocturne in D-flat Major, Op. 27, No. 2, by Frederic Chopin with the Vienna State Opera Orchestra, conducted by Sir Eugene Goossens. Kapp Records KDC - 6001, 1960, LP.

\section{Collaborative Recordings}

Prokofiev, Sergei. Two Sonatas for Violin and Piano. Wanda Wiłkomirska, (violin); Ann Schein, (piano). Connoisseur Society CS-2016, 1970, LP.

Rerelease: Prokofiev, Sergei. Two Sonatas for Violin and Piano. Wanda Wiłkomirska (violin); Ann Schein (piano). Connoisseur Society CS-4079, 1988, CD.

Repertoire:

Prokofiev: Sonata for Violin and Piano No. 1 in F Minor, Op. 80

Prokofiev: Sonata for Violin and Piano No. 2 in D Major, Op. 94a

Rorem, Ned. Night Music. Earl Carlyss (violin); Ann Schein (piano). Desto Records DC 7174, 1974, LP.

Rerelease: Rorem, Ned. Day Music, Night Music. Jamie Laredo (violin); Earl Carlyss (violin); Ruth Laredo (piano); Ann Schein (piano). Phoenix USA PHCD123, 1991, CD.

Repertoire:

Rorem: Night Music

Argento, Dominick and Ned Rorem. To Be Sung Upon the Water; King Midas. John Stewart (tenor); Sandra Walker (mezzo-soprano); Charles Russo (clarinet); Ann Schein (piano); Donald Hassard (piano). Desto Records DC 6443, 1975, LP. 
Rerelease: Rorem, Ned. Ariel, Gloria, King Midas. Phyllis Curtin (soprano); Helen Vanni (mezzo-soprano); John Stewart (tenor); Sandra Walker (mezzo-soprano); Ryan Edwards (piano); Ann Schein (piano). Phoenix USA PHCD126, 1991, CD.

Repertoire:

\section{Rorem: King Midas}

Laredo, Jaime (violin) and Ann Schein (piano). Copland, Ives, Binkerd. Desto Records DC 6439, 1975, LP.

Rerelease: Chamber Music for Violin and Piano. Jaime Laredo (violin); Rafael Druian (violin); Ann Schein (piano); Ilse von Alpenheim (piano); Ruth Laredo (piano); Phoenix USA PHCD 136, 1988, CD.

Repertoire:

Copland: Sonata for Violin and Piano

Ives: Sonata for Violin and Piano No. 4 (“Children's Day at the Camp Meeting")

Binkerd: Sonata for Violin and Piano in Three Movements ${ }^{143}$

The American Chamber Players. Harbison: Twilight Music for Horn, Violin and Piano; Variations for Clarinet, Violin and Piano; Rochberg: Piano Quartet. Koch International Classics 3-7027-2, 1990, CD.

Repertoire:

Harbison: Twilight Music for Horn, Violin and Piano

Harbison: Variations for Clarinet, Violin and Piano

The American Chamber Players. Stravinsky: L'oiseau de feu No. 2; Duo Concertante (plus suite from L'Histoire du Soldat; pieces from The Firebird, The Fairy's Kiss, and Mavra; and other chamber music." Koch International Classics 3-7078-2, 1991, CD.

Repertoire:

Stravinsky: Duo Concertant for Violin and Piano

${ }^{143}$ This work is not included on the rerelease CD. 
Stravinsky: Six Pieces for Violin and Piano (Arr. 1933-1947)

The American Chamber Players. Ernest Bloch: Quintets Nos. 1 and 2 for Piano and Strings. Koch International Classics 3-7041-2, 1991, CD.

Repertoire:

Bloch: Quinet No. 2 for Piano and Strings

Berg, Alban. Jessye Norman (soprano); Ann Schein (piano); the London Symphony Orchestra conducted by Pierre Boulez. Sony LC 6868, 1995, CD.

Repertoire:

Berg: Jugendlieder (selections)

Berg: Zwei Lieder

Landgren, Peter (horn) and Ann Schein (piano). A Golden Horn. Elan Records 82260, 2000, CD.

Repertoire:

Schumann: Phantasiestücke for Clarinet and Piano, Op. 73

F. Strauss: Nocturno for Horn and Piano, Op. 7

Rheinberger: Sonata for Horn and Piano in E-flat Major, Op. 178

Schumann: Adagio and Allegro for Horn/Cello and Piano in A-flat Major,

Op. 70

Pilss: Tre Pezzi in forma di Sonata

Walton, William. Walton: Suite from Henry V; Cello Concerto; Violin Sonata; Rands: Tre Canzoni Senza Parole. Oregon Symphony conducted by James DePriest; Mark Kosower (cello); Herbert Greenberg (violin); Ann Schein (piano). Delos International DE 3342, 2005, CD.

Repertoire:

Walton: Sonata for Violin and Piano 


\section{Compilations}

Piano Reflections: Moonlight Sonata. Various. Reader's Digest RDA 82-A, 1969, 4 LP's.

Repertoire:

Unknown

Ivory Classics $5^{\text {th }}$ Anniversary. Various. Ivory Classics, 72010, 2002, CD.

Repertoire:

Mozart: Sonata No. 16 in C Major, K. 545

Chopin, Frederic. A Century of Romantic Chopin. Various. Marston Records 54001-2, 2011, 4 CDs.

Repertoire:

Chopin: Étude in A-flat Major, Op. posth.

\section{Recent Recordings}

Schein, Ann (piano). Schumann: Davidsbündlertänze, Op. 6; Arabeske, Op. 18; Humoreske, Op. 20. Ivory Classics $71006,2000, \mathrm{CD}$.

Schein, Ann (piano). Chopin: Sonata in B Minor, Op. 58; 24 Preludes, Op. 28. MSR Classics MS1119, 2006, CD.

Schein, Ann (piano). Carter: Piano Sonata; Copland: Piano Variations; Sonata for Violin and Piano; Patitucci: Lakes with Earl Carlyss (violin). MSR Classics, MS1321, 2008, CD.

Ann Schein Live. Ann Schein (piano). ACA Digital Recording, Inc., CM20119, 2014, CD.

Repertoire:

Beethoven: Sonata No. 26 in E-flat Major, Op. 81a ("Les Adieux")

Carter: Piano Sonata

Rachmaninoff: Étude-Tableaux in E-flat Minor, Op. 33, No. 6 
Rachmaninoff: Étude-Tableaux in E-flat Major, Op. 33, No. 7

Chopin: Étude in F Major, Op. 10, No. 8

Chopin: Étude in C-sharp Minor, Op. 10, No. 4

Chopin: Étude in C Minor, Op. 25, No. 12 


\section{BIBLIOGRAPHY}

“Ann Schein.” Aspen Music Festival and School.” Accessed January 12, 2021.

https://www.aspenmusicfestival.com/students-welcome/admissions/artist-faculty/ann-s chein-1/.

“Ann Schein.” Johns Hopkins Peabody Institute, December 5, 2012. Accessed January 12, 2021. https://peabody.jhu.edu/alumni/award-winners/ann-schein-2/.

“Ann Schein, piano.” Musicians Club of New York. Accessed January 12, 2021. https://www.musiciansclubofny.org/biographies/annschein.

Aspen Music Festival and School. "Janice Carissa Master Class with Ann Schein." YouTube video, 24:29. December 1, 2015. https://www.youtube.com/watch?v=PYKYjis15LM.

Ax, Emmanuel and Ann Schein. "Remembering Mieczysław Munz with Emmanuel Ax and Ann Schein." Virtuoso 1, no. 71 (1980) 14-16.

Bachus, Nancy. "How did your studies with a world-renowned interpreter of Chopin's music impact your own playing and teaching of Chopin?" Keyboard Companion 17, no. 4 (Winter 2006): 38.

Biola University. "Women Composers, Performers and Impresarios [CCCA Cultural Conversation]." YouTube video, 1:01:22. November 12, 2014. https://www.youtube.com/watch?v=JTdvCiNSwk0.

Burwasser, Peter. "Piano Sonata./ Piano Variations. Violin Sonata./ Lakes." Fanfare: The Magazine for Serious Record Collectors 33, no. 2 (Nov./Dec. 2009): 146-147.

Chopin, Frederic. Liner notes for A Century of Romantic Chopin. Various. Marston Records B0064CRGLY, 2011, 4 compact discs.

Cook, Paul. “Ann Schein.” American Record Guide 72, no. 5 (Sep./Oct. 2009): 238-239.

Cook, Paul. "Piano Sonata/Variations; Violin Sonata/Lakes." American Record Guide 73, no. 1 (Jan./Feb. 2010): 137.

Distler, Jed. "Carter. Copland. Patitucci." Gramophone 87, no. 1048 (Sep. 2009) A5.

Emotional connection with students: why one cannot teach without it. DVD. Produced by Benjamin, Saver; Independence, KY. 
Hughes, Walden. "Schumann.” Clavier 41, no. 1 (Jan. 2002): 30-31.

Isler's Insights. "Interview with Ann Schein and Earl Carlyss: Part 1 of 2." Facebook, September 5, 2019. https://www.facebook.com/islersinsights/posts/21410444339333002.

Isler's Insights. "Interview with Ann Schein and Earl Carlyss: Part 2 of 2." Facebook, September 6, 2019. https://www.facebook.com/islersinsights/posts/2142804255823687.

Kiraly, Philippa. "Frederick Chopin." Clavier 45, no. 10 (Winter 2006): 32.

Litzelman, James. “Ann Schein: Pupil, Performer, Teacher." American Music Teacher 64, no. 3 (December 2014 - January 2015): 30-34.

Lee, Sora. “The Life and Legacy of Mieczysław Munz.” DMA diss., West Virginia University, 2016. ProQuest Dissertations and Thesis Global.

Kentucky Music Teachers Association. "Beethoven: My Musical Journey - Ann Schein." YouTube video, 44:59. September 25, 2020. https://www.youtube.com/watch?v=Q9K4i2uwzwc\&t=195s.

Markowicz, Roman. "Chopin's interpretations that composer himself might have approved of." ConcertoNet.com. Accessed January 12, 2021. http://www.concertonet.com/scripts/review.php?ID_review=14489.

McKenna, Marian C. Myra Hess: A Portrait. London: Hamilton, 1976.

Modi, Sorab and Elizabeth N. Morgan. "Schein, Ann." Grove Music Online, May 25, 2016. https://wwwoxfordmusiconlinecom.www.libproxy.wvu.edu/grovemusic/view/10.1093/g mo/9781561592630.001.0001/omo-9781561592630-e-1002293005.

Munz: A Pianist’s Story. DVD. Produced by Lucy Mauro, 2020.

"Performance History Search: Ann Schein." Carnegie Hall. Accessed February 2, 2021. https://www.carnegiehall.org/About/History/Performance-HistorySearch?q=ann\%20schein\&dex=prod_PHS.

Porter, Cecilia Hopkins. "Ann Schein: An American Concert Pianist in Today's World." In Five Lives in Music: Women Performers, Composers, and Impresarios from the Baroque to the Present, 148-196. Champaign, IL: University of Illinois Press, 2012.

Sachs, Harvey. Rubinstein: A Life. New York, NY: Grove Press, 1995.

Schein, Ann. "The Music of Chopin - my legacy from Mieczysław Munz and Arthur Rubinstein." Keyboard Companion 17, no. 4 (December 2006): 38-41. 
Schein, Ann. "Dear Mom.” Clavier Companion 3, no. 4 (Jul/Aug 2011): 9-10.

Schein, Ann. "Memories of a Cherished Friendship." Pan Pipes 112, no. 2 (Winter 2020): 10-11.

Schein, Ann. “Ann Schein KJAX Radio Interview.” YouTube video, 24:11. September 13, 2012. https://www.youtube.com/watch?v=zbmIkfRIWo.

Schein, Ann. "Ann Schein Master Class." YouTube video, 3:10. July 21, 2014. https://www.youtube.com/watch?v=-WXWsjSS6x8.

Schein, Ann. "Franz Liszt: Tarantella from 'Venezia e Napoli,' Book II from Annees de Pelerinage." YouTube video, 10:18. September 13, 2012. https://www.youtube.com/watch?v=UUswOwyaB_Y.

Schein, Ann. "Ravel: Sonatine.” YouTube video, 12:53. September 5, 2012. https://www.youtube.com/watch?v=Qv8z5PhLwMs.

Schein, Ann. "Chopin: Nocturne in E-flat Major, Op. 55, No. 2." YouTube video, 5:40. September 5, 2012. https://www.youtube.com/watch?v=Kmg82BlazKk.

Schein, Ann. "Chopin: Ballade No. 4 in F Minor, Op. 52." YouTube video, 11:32. September 5, 2012. https://www.youtube.com/watch?v=cyKaruP4Ls.

Schein, Ann. "Elliott Carter: Piano Sonata (1945-46)." YouTube video, 7:20. September 5, 2012. https://www.youtube.com/watch?v=GP-152jzbyA.

Schein, Ann. Ann Schein. Accessed September 22, 2020. https://www.annschein.com/.

Wagner, Jeffrey. “Ann Schein Teaches to inspire pianists." Clavier 41, no. 1 (January 2002): 1017.

Weirich, Robert. "Winds of Change." Clavier Companion 3, no. 2 (Mar./Apr. 2011): 6-7.

Wong, Jerry. "Inspiration and concrete suggestions." Keyboard Companion 17, no. 4 (Winter 2006): 42-43. 